\title{
7 Coranderrk, Photographs and Tourist Postcards
}

J.M. MacKenzie (1985) has shown how the late nineteenth century imperial world view was an integral part of the commercial, industrial and social revolutions which took place in Britain between the 1850s and 1914. British society achieved nearly universal literacy and dramatic changes occurred in patterns of consumption as unrivalled opportunities for leisure and entertainment emerged and a voracious demand for collectible items. Printed and visual materials became so cheap that they were found in almost every home - it was a form of mass media that preceded the cinema, radio, and television. Picture postcards, cigarette cards, and juvenile journals could be collected and swapped - indeed, the period from the late 1890s to 1918 has been seen as the golden age of these collectables.

Photography offered a new visual revolution - from the 1850s travelling photographers set out to satisfy a demand for exotica and a visual presentation of the intrusion of the West around the world. The camera became a coloniser, a preparer of the route to European expansion in the late nineteenth century. Carte de visite photographs became popular with the middle classes and stereoscopes which had been invented in 1851 became very popular from the 1860s. However the advent of the postcard was the central element of the ephemera boom of this period the height of the popularity of the postcard is generally regarded as between 1898 and 1918. Postcards took over from stereoscopes and visual paper and envelopes. MacKenzie (1985: 23) has noted how large numbers of cards were produced of the Empire itself, recording colonial products, and such things as visits of governors and royalty, and 'ethnics' showing the whole range of indigenous peoples under imperial rule.

Peterson (2006:11) has argued that postcards were the first genuinely popular access ordinary people had to photography. Improvements in printing technology made it possible to produce a postcard far cheaper than the cost of a Carte de Visite. Industrially produced postcards, what Peterson calls 'process printed images' were produced by photographers and companies with access to a large number of images to choose from. The other kind of postcards that were in circulation at this time was hand printed photographic images, produced and distributed by local photographers. These were not mass produced and were often sold in very small numbers from a select number of localities.

Poole (in Haebich, 2009) notes that colonial photographs were part of a 'visual economy'- they were produced, distributed, circulated, and consumed. In the late nineteenth century colonial photographs became images of scientific racial typologies, anthropometric evidence, salvage data, and government propaganda. Kleinert (2006: 70), cautions, however, that in arguing for the authority of photographic images, it is possible to lose light of the complex factors at work in cross-cultural representation including 'the dynamics of the historical encounter, the conditions of production and reception and the willing participation of Indigenous subjects creat- 


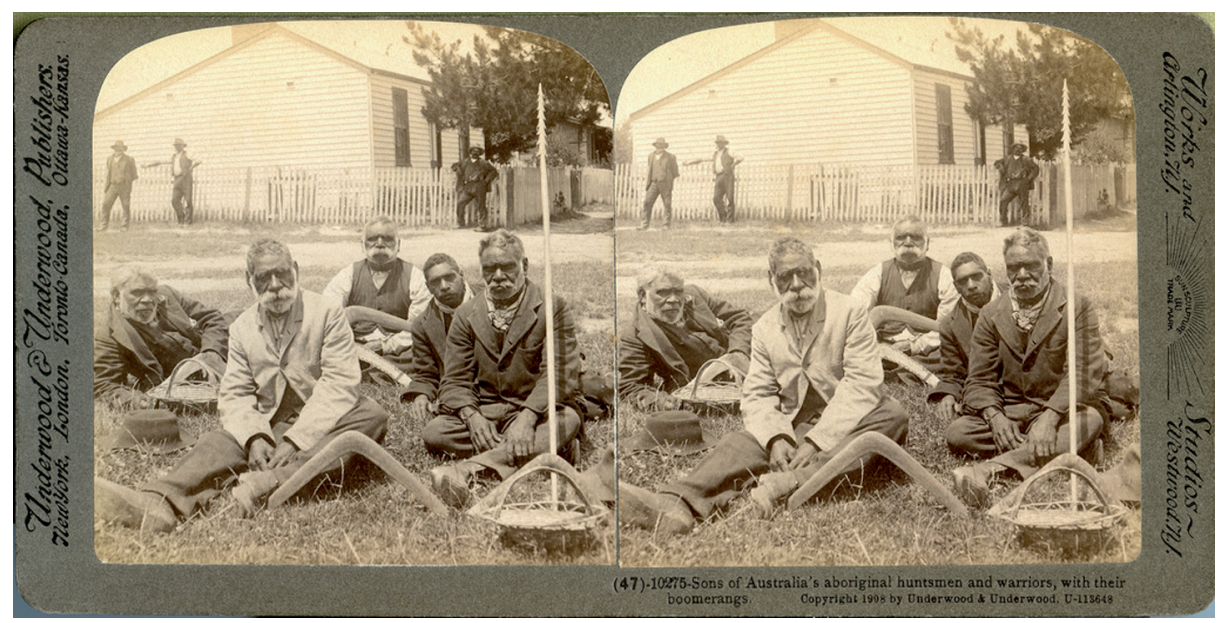

Figure 7.1: Sons of Australia's aboriginal huntsmen and warriors, with their boomerangs.

(Active no. (47)10275 S990) 1908. Underwood \& Underwood (publisher), James Ricalton (photographer. Series Title: Australia \& New Zealand Tour. Source: author's picture collection.

ing the possibility for many and varied readings'. Photography is now seen to allow more varied and diverse interpretations - images are polysemous.

Lydon's (2005: xiii) analysis of colonial photography at Coranderrk is that it became a powerful visual language: one that was shaped through a process of exchange as seen through the circulation of images through the press and commercial photography. Knowing how they were represented in white discourse allowed the residents to manipulate the public debate. Thus Lydon suggests it is possible to recover a performative relationship between the image and Aboriginal subjects, making it possible to interpret images and postcards from Indigenous perspectives.

Haebich's (2009: 57) analysis of the early photography taken at Coranderrk is that it is dominated by tangible evidence of progress: cleared lands under crop, new buildings, Aboriginal children surrounded by the trappings of civilised life, sedentary families posed in the manner of colonial settlers outside their cottages, and scenes of community outings were residents relax on river side picnics or engage in the manly sports of cricket. Details of composition, the subjects' clothes, grooming and posturing, and contextual props all combine to provide compelling proof of the missionaries'success. For Lydon, these images are an essential part of the colonial project of knowing and governing Aboriginal people (Haebich 2009: 58). But Lydon rejects the interpretation that Aboriginal people were captured and coerced by the photographers - she calls for a nuanced reading of the relationship between photographers and their Aboriginal subjects. Haebich (2009: 58) cautions, however, that given that we can create new meanings simply through the act of looking at photographs, how then do we avoid interpreting them according to the agendas that we 
want to demonstrate? Peterson's response, according to Haebich (2009: 58), is that generalized fictions of colonialism ought to be avoided by studying examples of localized practice. Kuhn and McAllister (in Haebich, 2009: 59) suggest photographs need to be located and studied in situ: learning how and where they circulated in colonial visual economies across time and place, identifying the contexts that produced them and the tropes and conventions that gave them meaning.

Morton (2006) addresses the problems of how we relate to photographs. He asks how is it that a photograph that seemed to say one thing when it was created in 1866, for example, came to say something completely different 134 years later. The photograph itself, which is in a sense immutable, has not changed. His answer is that what has changed is the way the "particular photograph is perceived, the way in which it is contextualised and enlisted to tell stories, and the way that people find themselves and their identities in those stories' (Morton 2006: 50). Photographs 'trigger subjective acts of recognition and feelings attendant on those acts, thereby providing concrete evidence of a deeply felt connection to the past' (Morton 2006: 50). Kovacic (2006: 99) reminds us that the photographic image is 'polysemic' and that it can carry many different meanings.

Kovacic (2006: 92) has noted how Lydon's research into photography at Coranderrk 'has questioned the inevitability of photography as a tool of surveillance and control, and examined Aboriginal agency in the picture-making process'.

With the exception of those times when professional photographers were commissioned to take photographs of Coranderrk (such as Charles Walter in 1866 and Fred Kruger in the 1880s), Kovacic has observed that colonial photographers usually photographed Aboriginal people out of their own interest or because they knew such photographs would do well on commercial markets in colonial and overseas urban centres. Thus moneymaking was a significant motive for taking photographs of Aboriginal people. Linking it with the indigenous body trade, Kovacic argues the 'views trade' was a reflection of the growing demand of Australian images.

Peterson (in Kovacic, 2006: 97) has argued that 'Any photographic encounter required a significant level of cooperation from the Aboriginal people concerned'. Kovacic has observed that some of the studio portraits of Aboriginal individuals and families 'show people who were not only willing but even looking forward to having their photographs taken' (Kovacic, 2006: 97). 'Many Aboriginal models, both in studio portraits and in group photographs taken at missions, strike the viewer as powerful and proud individuals who are either stubbornly defying the gaze of the camera or evidently taking great pride and pleasure in having their picture taken' (Kovacic, 2006: 97).

In this chapter I will follow Peterson's (2006: 13) analysis of select postcards. When Peterson began his analysis he was struck by two observations: that the hand printed photographic prints were generally more sympathetic and attractive pictures of Aboriginal people than the mass-produced process printed cards; secondly, he was surprised that the process printed cards had any commercial potential given the low 


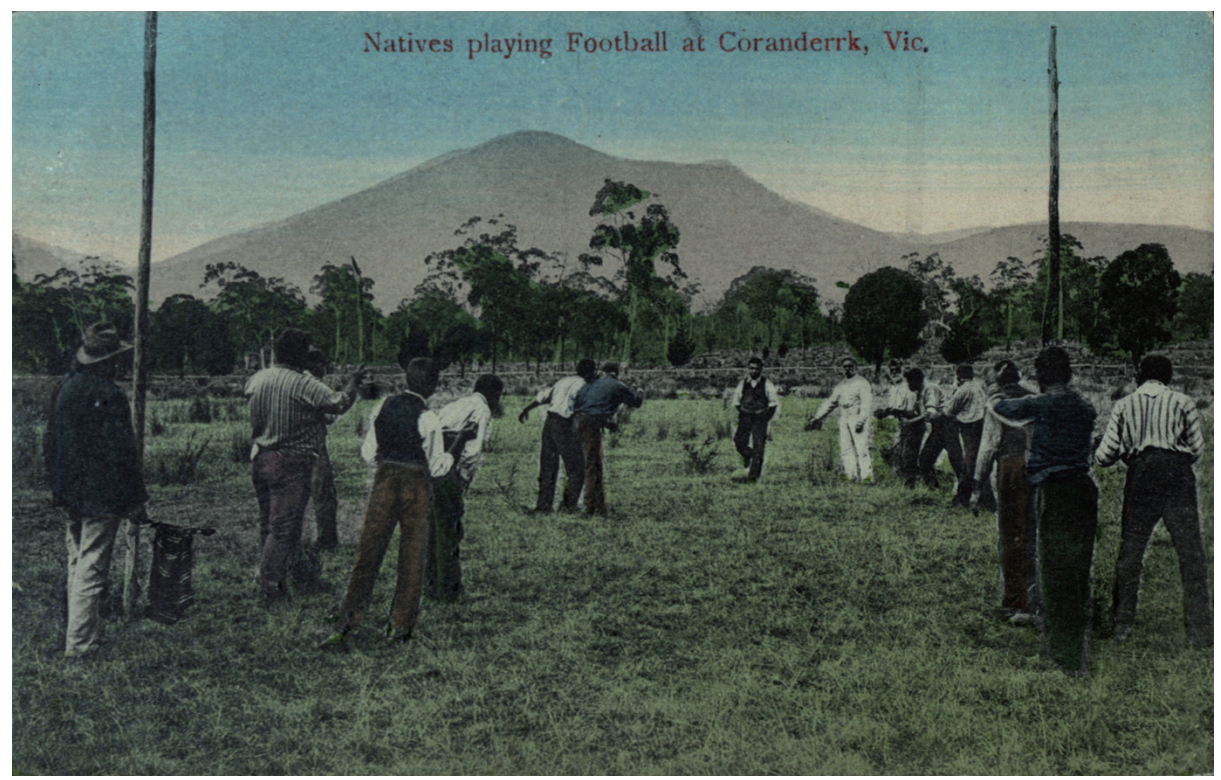

Figure 7.2: Natives playing Football at Coranderrk, Vic. N.J. Caire photographer. V.S.M. Series. Printed in Germany. (Author's picture collection).

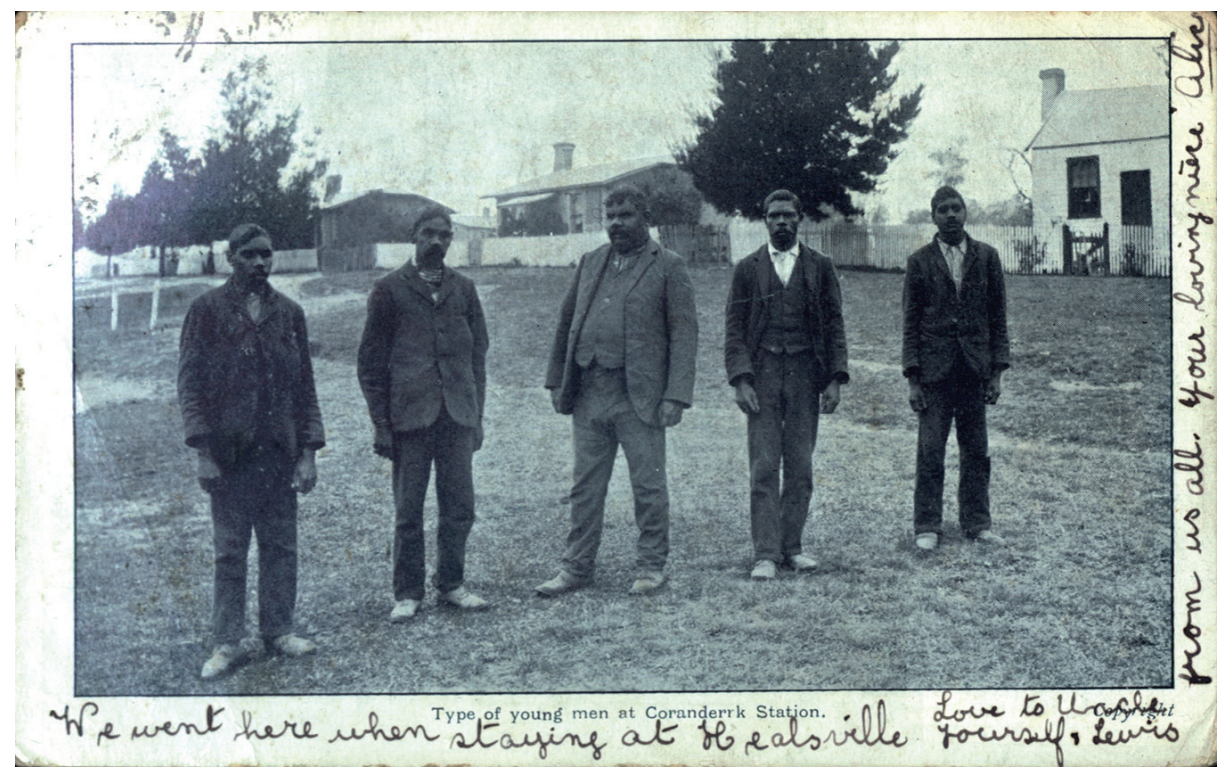

Figure 7.3: Type of young men at Coranderrk Station. N.J. Caire photographer. (Author's picture collection). 'We went here when staying at Healesville.' The man in the centre is Woodford Robinson. 
aesthetic quality of their images. Because Lydon (2005) has made an intensive study of Charles Walter and Frederick Kruger their Coranderrk photography is not considered in this study.

\subsection{Nicholas Caire}

Nicholas John Caire was born at Guernsey on 28 February 1837 and immigrated to Adelaide, South Australia, in c. 1860 with his parents. In 1865 he was travelling through Gippsland taking photographs of Aboriginal people at Lake Tyers and landscapes in the Strzeleki Ranges. In 1867 he opened a studio in Adelaide, married in 1870 and moved to Talbot on the Victorian goldfields. In 1876 he opened a studio in Melbourne. In 1885 he moved his studio to South Yarra. He died in 1918, aged 81 (Cato, 1955: 76f). In 1904 Caire was commissioned to produce a series of photographs for the Japanese Colonial Department (Lydon, 2005: 189). These photographs were turned into a series of postcards, examples of which are published here (see Figures 7.2-7.10, 7.13-7.14).

Lydon (2005: 190) has argued that Caire's images of Coranderrk proved to be very popular souvenirs, particularly between 1902 and 1914 when they were in vogue, and reached 'a wide national and international audience'. Many of his images were 'overtly staged, self-conscious performances by the residents, enacting both traditional activities' such as wrestling, corroboreeing, and making firesticks, and European routines such as dairying.

Figures 7.3 and 7.6 are both concerned with 'types': 'Type of young men at Coranderrk station' and 'Types of Aboriginal beauty, Coranderrk Station, Vic'. Peterson's (2005: 22) analysis of Figure 7.6, showing four women - three of whom are in the uniform of domestic helpers - is that the image is problematized by the caption which raises a whole set of other issues ... about attitudes to Aboriginal appearance, directing viewers' attention to the face rather than to the evidence of the desirable social effects of their institutionalization'. Figure 7.3 is in the same mode, 'directing attention to the physical appearance rather than the smart sartorial appearance that mark these men out from almost all other process printed images'.

Figures 7.4 and 7.5 involve the same three subjects - Lanky Manton dressed in cricket whites, Sam Rowan, and an unnamed youth: one card is entitled 'The Young Australian native learning to throw the Boomerang' has the young child standing about to throw a boomerang; sitting on the ground beside a collection of artefacts are Lanky Manton and Sam Rowan - in the background standing and leaning against and sitting on the fence is an audience of 16 Coranderrk residents - men, women, and children. The second card is entitled 'Boomerang throwing, Coranderrk Station, Vic' involves the same participants, only this time Lanky Manton is standing beside the artefacts holding the boomerang in his left hand. In both cards, Lydon (2005: 199) argues Caire, the photographer, 'stands as a tourist would have, looking over the clear space in front of the settlement, to watch a display of throwing the boomerang'. 


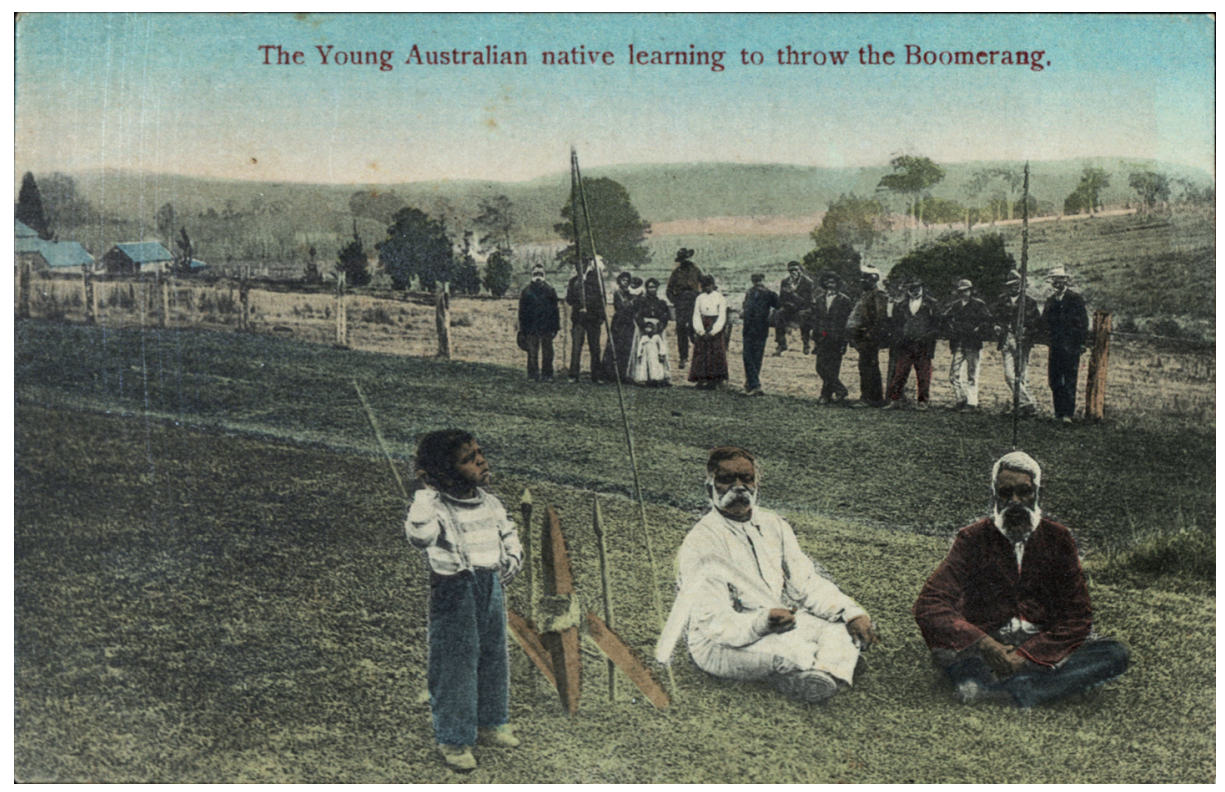

Figure 7.4: The Young Australian native learning to throw the Boomerang. N.J. Caire photographer. V.S.M. Series. Printed in Germany. (Author's picture collection).

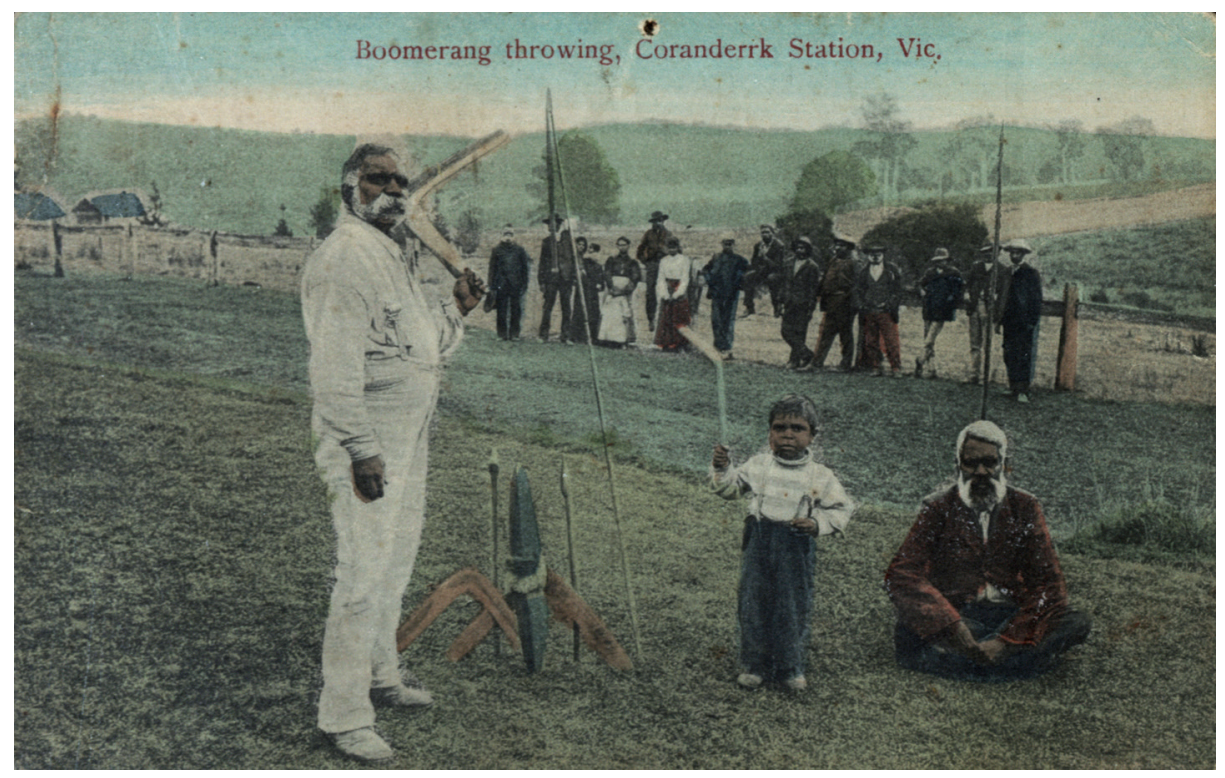

Figure 7.5: Boomerang throwing, Coranderrk Station, Vic. N.J. Caire photographer. V.S.M. Series. Printed in Germany. (Author's picture collection). Lanky Manton in whites; other older man is Dick Rowan. Child's name not known. 
Lydon (2005: 191) argues that some of the other postcards that are derived from Caire photographs (See Figures 7.7-7.10) are structured by the trope of the availability of souvenirs in the forms of weapons or other artifacts such as baskets and rugs detached from traditional hunting and gathering they were relics of 'savagery'.

\footnotetext{
They have the same pictorial structure: in the center of the scene, at the back, spatially staked out by spears and array of smaller weapons, an elderly man [John Terrick] sits enveloped in a possum skin cloak, invoking a tradition originating in the earliest photographs of Australian Aborigines ... showing people sitting in a camp. The natural setting has been emphasized by cutting gum-tree branches to augment the natural backdrop. Less a focal point than a starting place, the old man and the traditional weapons he holds animate the Aboriginal past, metaphorically overshadowing the Aboriginal present. Against this static background Caire created decontextualized pseudodocumentary "moments" illustrating key aspects of tradition, including warfare and fire making, and the nomadism inferred by the line of women and children (Lydon, 2005: 191, 195).
}

Lydon concludes that these postcards reflect a populist understanding of traditional Aboriginal culture, signified by stereotypical Aboriginal objects and practices. 'They are stereotypes, distancing and objectifying the Aboriginal people'. They are 'the first to deliberately re-create tradition, with the cooperation of managers. The complicity of officials with commercial photography at this time reflects their acceptance of visual representations, and of the tourist industry that popularized them' (Lydon, 2005: 195).

Analysing the collection of Caire images that involve John Terrick (Figures 7.77.9) seated in the centre, Lydon (2005: 199) considers that 'the array of spears, spear throwers, clubs, shields, and boomerangs shown in 'Natives making Firesticks at Coranderrk, Vic.' (see Figure 7.7), resemble a curio stall or museum display'. She argues his 'posed tableaux' can be interpreted 'as a stylized, stereotypical re-creation of traditional customs for a contemporary audience, unfamiliar with Aboriginal people, through the inclusion of material markers of Aboriginality, enhanced by photographic realism'.

Lydon's analysis of Figure 7.13 The Dairy at Coranderrk Station, Vic. is that it shows 'residents in the midst of routines, many frozen in the act of taking a step, their rigid poses indicating careful arrangement. .. the manager Shaw, recognizable by his top hat and frock coat, stands prominently within the scene, symbolizing his pastoral relationship to the Aboriginal people. Pictorially, the rigidity of the subjects resonates with this textual trope of control: these images focus on regulated activities rather than individuals or their appearance (Lydon, 2005: 191).

Figure 7.14 has various titles. The one presented here is 'The first Cobbs' Coach Imported from America, Delivering H.M. Mails to the Natives at Coranderrk'. I have a second copy, an A.G.J. card, printed in Saxony, with the title 'Australian Aboriginals'. Cato (1955: 64) reproduces the same image with the caption 'Cobb's Coach off to Lake Tyers with its load of aboriginals, taken by Nicholas Caire, about 1884'. This date 


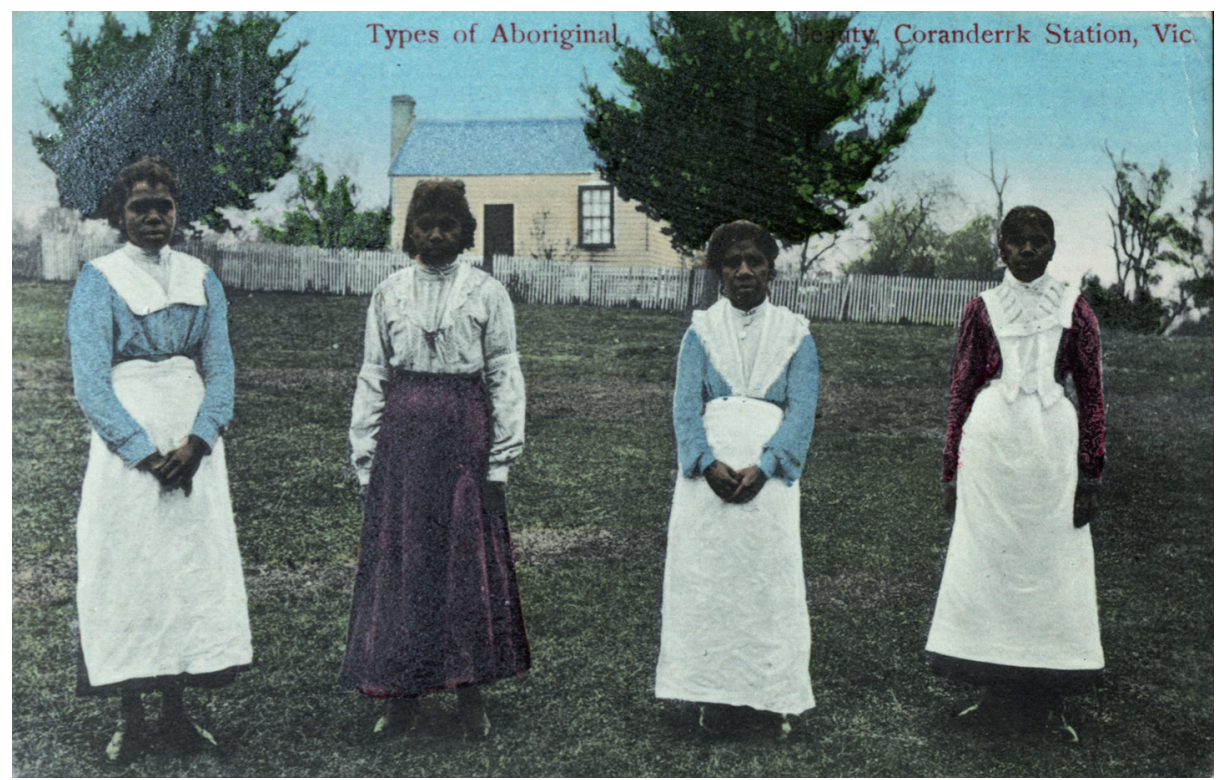

Figure 7.6: Types of Aboriginal Beauty Coranderrk Station, Vic. N.J. Caire photographer. V.S.M. Series. Printed in Germany. (Author's picture collection)

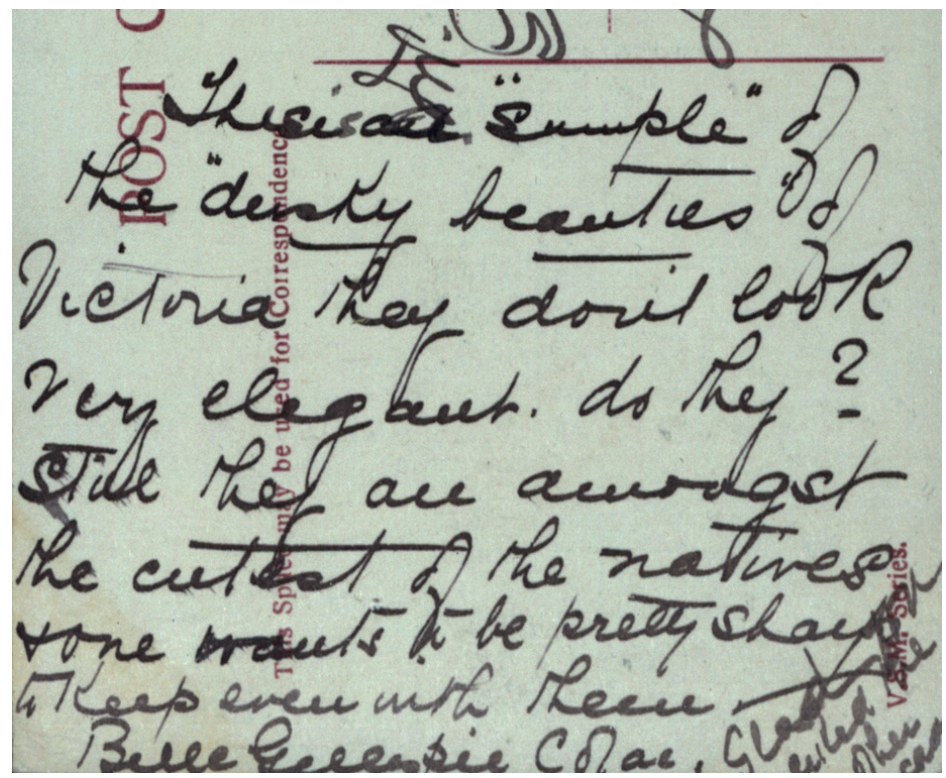

'This is one "sample "of the "dusky beauties" of Victoria. They don't look very elegant do they? Still they are amongst the cutest of the natives \& one wants to be pretty sharp to keep even with them'. 
seems incorrect; when the image of Joseph Shaw is compared to his image in other photographs taken in 1904, it suggests that the photograph is more likely to date from 1904 (Pitkethly \& Pitkethly, 1988: 68).

\subsection{James Ricalton, Underwood \& Underwood Photographer, 1908}

In 1908 noted photographer James Ricalton visited Coranderrk and took a number of photographs for his employer Underwood \& Underwood. James Ricalton (1844-1929) was a school teacher, inventor, traveller, and photographer who travelled extensively around the world. Ricalton was in Australia in 1907-8. The Riverine Herald (7/1/1908) referred to him as 'the most famous photographer in the world. The professor, who has taken photographs in all parts of the earth and under all sorts of trying circumstances, is now in Australia'. The Launceston Examiner (30/1/1912) called him the 'the dean of American photographers'. During his time in Australia he was the subject of an article in the December 1907 issue of Life written by W.A. Somerset in which Ricalton described his work and his methods. The Adelaide Chronicle (11/1/1908) discussed both Ricalton and the work of Underwood and Underwood, his employer.

The Underwood \& Underwood Company produced stereoscopes and stereoscopic images starting business in Ottawa, Kansas in the early 1880s. Brothers Elmer and Bert began by selling stereoscopes from door to door. By 1901 they were producing more than 25,000 cards a day and selling 300,000 stereoscopes a year. Opening branches in Baltimore, London, and Canada, they relocated to New York City in 1891. Malin (2007) in a study of stereoscope images has shown how Underwood \& Underwood linked the stereoscope to education and notions of citizenship suggesting that they could help teach subjects such as geography. To accompany their vast collections of stereoscopes Underwood \& Underwood and their primary competitor the Keystone View Company published books that they intended to accompany their collections. The stereoscope was promoted as a means through which middleclass audiences could gain access to cultural knowledge and cultural capital usually associated with upper class travel. The three-dimensional stereoscopic 'tour' was promoted by these companies as 'close to travelling by magic carpet as anyone can outside of a fairy tale' (Malin, 2007: 409). Given that international travel was out of the reach of most people, the stereoscopic tours of foreign countries were framed as sources of enlightenment and cultivation.

The stereoview that was produced from this visit to Coranderrk was captioned 'Sons of Australia's aboriginal huntsmen and warriors - with their boomerangs' (see Figure 7.1). It was part of a teaching series entitled 'Australia \& New Zealand Tour'. In terms of the identity of the five men, I believe them to be from left to right: Sam Rowan; Lanky Manton; Woodford Robinson; Harry McRae; Ned McLennan. The three men in the background are not known.

On the reverse of the stereoview are the following notes: 


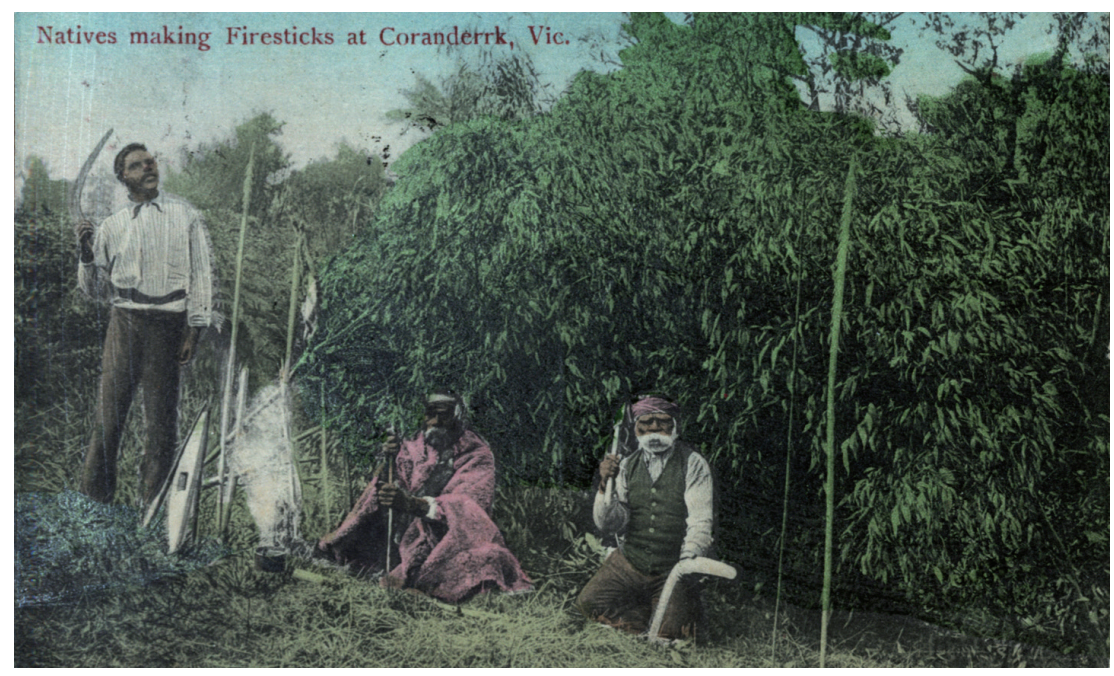

Figure 7.7: Natives making Firesticks at Coranderrk, Vic. N.J. Caire photographer. V.S.M. Series. Printed in Germany. (Author's picture collection).

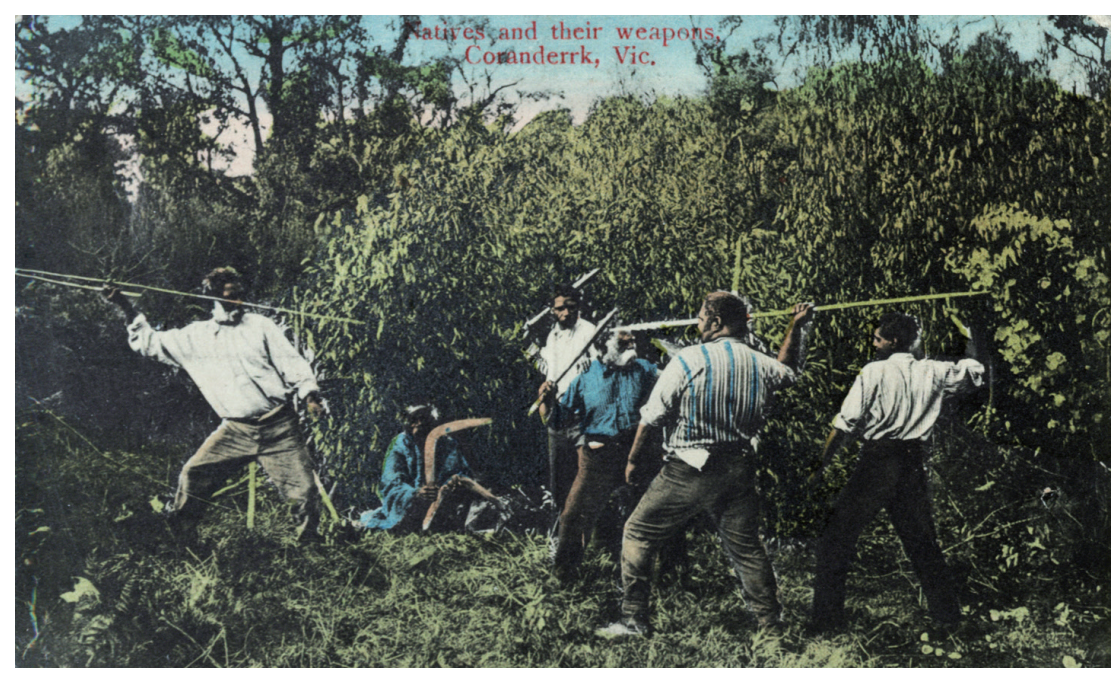

Figure 7.8: Natives and their weapons, Coranderrk, Vic. N.J. Caire photographer. V.S.M. Series. Printed in Germany. (Author's picture collection). ${ }^{135}$

John Terrick seated in both. Man kneeling in Figure 7.7 is Lanky Manton; in Figure 7.8 Manton is standing and wearing blue shirt. Man with back to us standing closest to Manton is Woodford Robinson. In Figure 7.8 man on far left is Sam Rowan.

135 The State Library of Victoria has a black and white postcard of this image entitled 'Fun in Camp Coranderrk'. Pictures Collection Accession No. H141235/2. 
10275. Geography. - We are at Healesville on the Yarra river, a few miles northeast of Melbourne, in Victoria, Australia.

People and Homes.- Healesville is a reservation which has been set apart by the government for the Australian aborigines. They are allowed to occupy cheap wooden houses like those in the background and are provided with food and clothing by the government. In return for this care, they are supposed to do a certain amount of work.

The native weapon for war and amusement is the boomerang, of which we see several specimens here. There are two kinds, one which can be thrown a distance of one hundred and fifty to two hundred and seventy five yards with power enough to kill game; the other, which is used more for amusement, can be thrown in such a way that it will return to the sender, in apparent violation of all mechanical laws.

Races of Mankind.- The origin of the natives of Australia presents a difficult problem. The chief difficulty in deciding their critical relations is their remarkable physical difference from all the neighbouring peoples. And as one turns from physical criteria to their manners and customs, it is only to find fresh evidence of their isolation. While their neighbours - the Malays, Papuans and Polynesians - all cultivate the soil, and build substantial huts and houses, the Australian natives to neither. Pottery is common to Malays and Papuans, but is unknown to the Australians. The bows and arrows of the Papuans and the elaborate canoes of all three neighbouring races are also unknown to the Australians. They must be considered as representing the most primitive race of mankind, and it is necessary to look far for their prehistoric home.

Refer again to this view when considering History, Agriculture, Manual Training.

There are numerous copies of this view in the medium of silver gelatin on glass in the National Museum of American History in the Smithsonian Institution in Washington. Their catalogue entries provide a creation date of 1908. The photographer is listed as James Ricalton.

Stereoview 990 was considered suitable for class discussion of the following topics: People - Their Dress and Manners; Special Groups of Buildings - Cottages; General History - Australia and New Zealand; Homes and Life of the People; Fundamental Handicraft - Wooden implements; Races of Mankind - Australians; People; People - Black; and Regions with Winter Rain - Victoria (Australia) (see McMurray 1915).

The next image in the Australia and New Zealand Tour series is '10276: Boomerangs in mid-air, on the curving flight which will bring them back to the thrower, New South Wales', 1908.

In the set of 1,000 stereographs, only 11 were of Australia -Nos. 982-992: including 982 - Melbourne; 983 - Collins Street, Melbourne; 984 - kangaroo at Melbourne Zoo; 987 - Tower Hill, Koroit; 988 - gold mine, Bendigo; and 990 - Aboriginal men at Coranderrk.

McMurray (1915: iv) stressed that 'Using stereographs is not play; it is work. The stereograph is a superior kind of text, and a good teacher will not have so much trust in mere print that he will be unwilling to go to some trouble to get the most out of this 


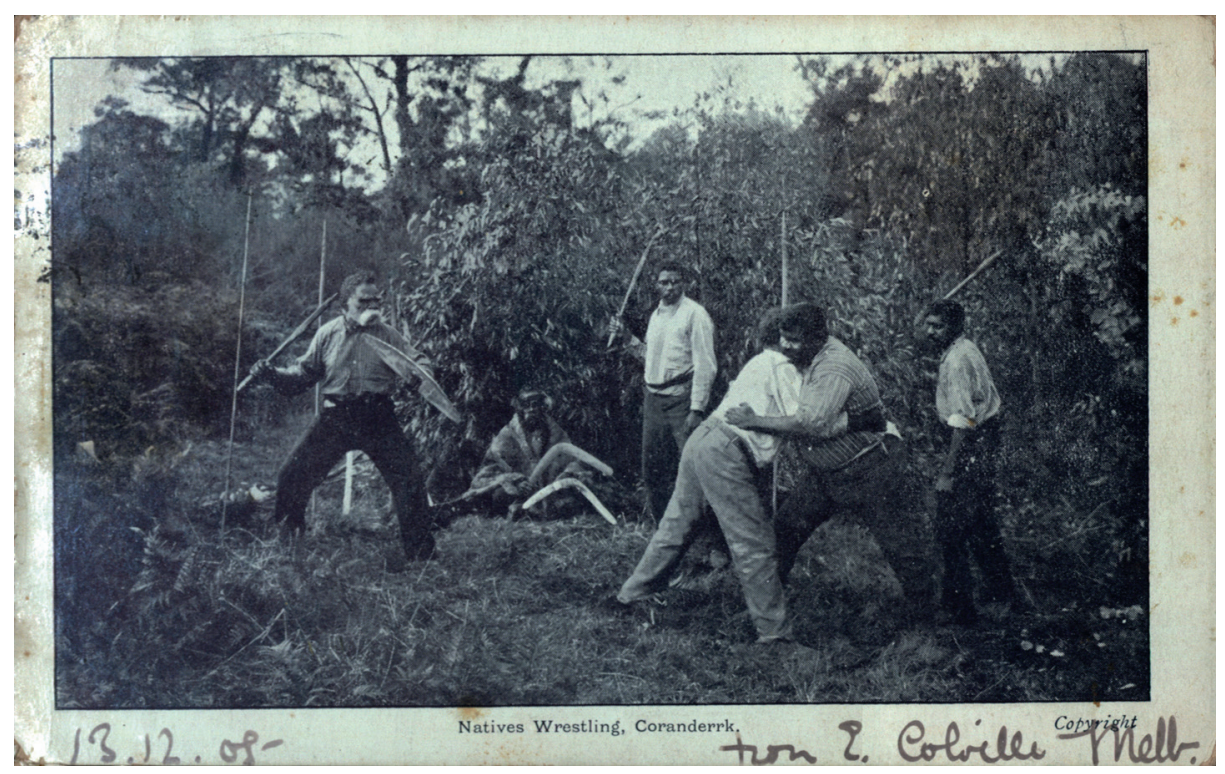

Figure 7.9: Natives wrestling, Coranderrk. (Author's picture collection). John Terrick seated. Lanky Manton far left. Wrestler on right is Woodford Robinson.

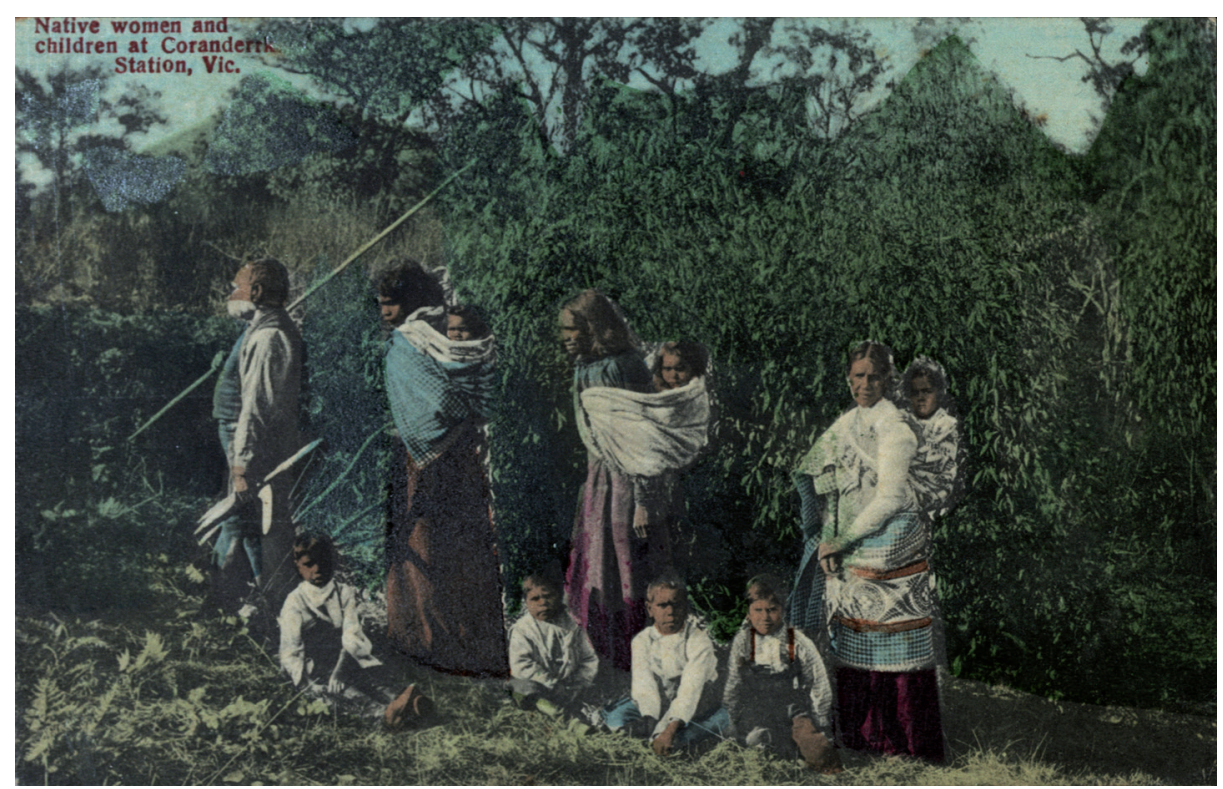

Figure 7.10: Native women and children at Coranderrk Station, Vic. N.J. Caire photographer. V.S.M. Series. Printed in Germany. (Author's picture collection). 
higher kind of text. Let him realize that the stereograph is a true window to the world of nature and the activities of man, by means of which the pupils may:

Through the loop-hole of retreat

Peep at such a world;

Hear the great Babel

And not feel the crowd (McMurray, 1915: iv).

McMurray (1915) also stressed the importance of the descriptive text that accompanied the stereoscope:

\begin{abstract}
An important feature of this series that greatly adds to its value both for reference and for class use, is the excellent descriptive and explanatory text on the back of every stereograph card and which is supplied separately for each slide. These explanatory and technical descriptions cover all the most important points in connection with each subject shown. This text has been carefully prepared and will be found of much importance to both teacher and pupil, rendering it unnecessary to hunt here and there for information about places or objects shown. This is provided in the text so as to be instantly available. It supplements the regular text-books of the schools in a most valuable manner. For convenience of reference, the descriptive text is often divided under several of the school topics for which any particular stereograph or slide is likely to be of special use. For example, the text for No. 1 is under the headings of Geography, Literature, Geology, Architecture and History; or No. 59 under Geography, Agriculture, Industries, People and Homes, History (McMurray, 1915: xxviii).
\end{abstract}

\title{
7.3 Healesville photographers: Ernest Samuel Fysh and J. \& O.H. Kercheval
}

In the early twentieth century, Healesville and Coranderrk were served by numerous professional photographers including Ernest Samuel Fysh and the Kercheval Brothers - J. \& O.H. Kercheval - the latter do not receive any attention from Lydon (2005). Very little is known of the Kercheval brothers but from articles in the Healesville and Yarra Glen Guardian it is clear that they were active during the period from 1910 until at least 1912 when they are recorded as having taken photographs for tourist publications such as the Penny Guide Book. The Healesville and Yarra Glen Guardian (31/5/1912) noted that 'Mr Kercheval is gaining a wide reputation as an up-to-date photograper'. In July 1912 the local paper reported that 'Mr Coffey, assistant Government Tourist Officer, wrote to the last meeting of the Healesville Tourist and Progress Association, stating he intended, for general information regarding Victoria, to make a post card collection. He asked that the Association procure and forward views of Healesville and district. It was decided to request Messrs Kercheval, Fysh, Lindt and Caire to kindly supply the views' (Healesville and Yarra Glen Guardian, 12/7/1912).

Figure 7.15 is an example of a Kercheval Bros photograph. Peterson (2005: 19) has analysed this photograph and notes that the 'people are well dressed by Australian 


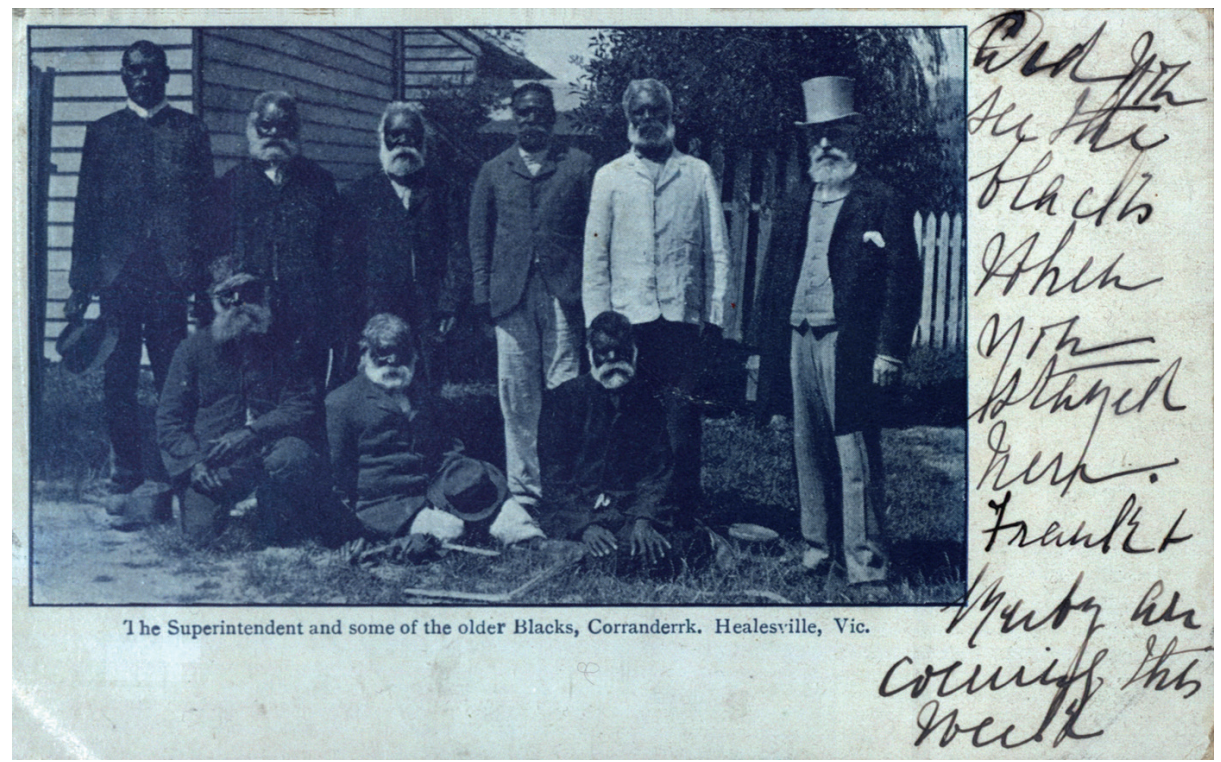

Figure 7.11: The Superintendent and some of the older Blacks, Coranderrk, Healesville, Vic. (Author's picture collection). 'See the blacks when you stayed here'.

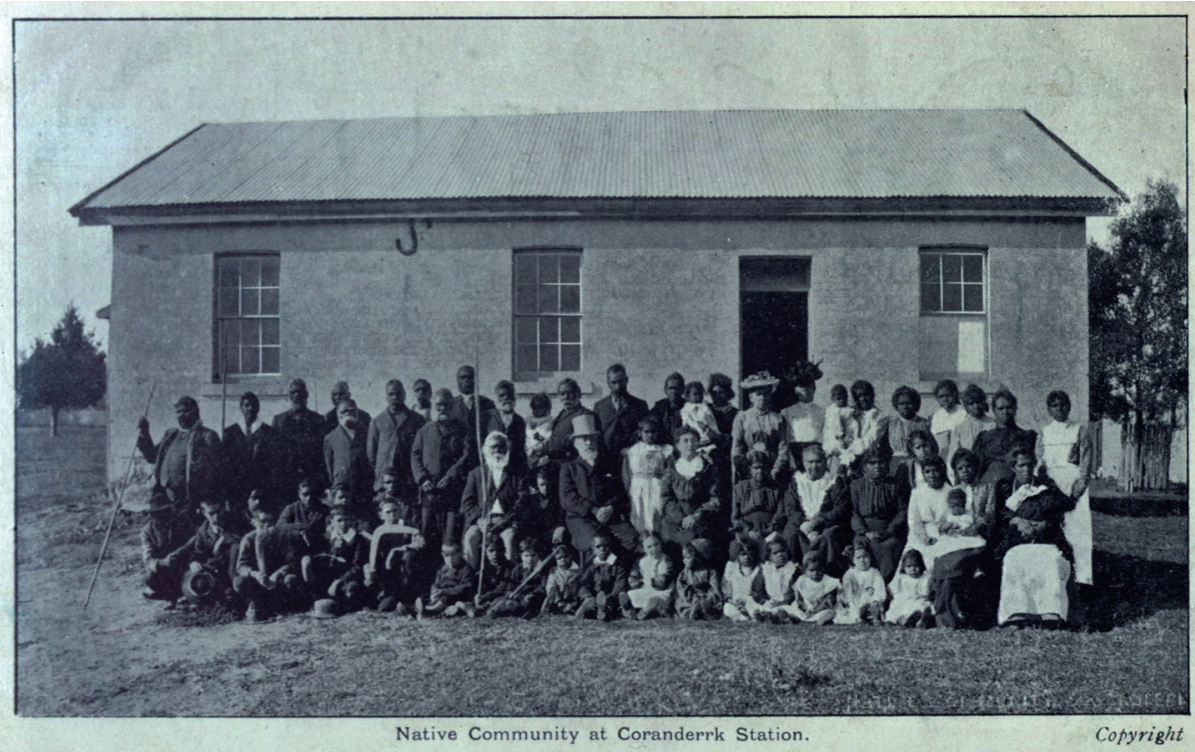

Figure 7.12: Native Community at Coranderrk Station. (Author's picture collection). Woodford Robinson far left back row - note his distinctive stand which he reproduces in many photographs. 
standards of the day, the adults are sitting on chairs and a boy is even wearing a school cap'. Other Kercheval photographs include Figures 7.18, 7.20 and 7.21.

Ernest Samuel Fysh (1876-1942), teacher, photographer, publisher and poet, established himself as a photographer in Healesville in 1908. On 8 September 1909, Fysh visited Coranderrk Station and took photographs of the Aboriginal residents. Natalie Robarts wrote in her diary: 'We had quite a little pleasant disturbance, Mr. Fish the photographer came to take several photos of the natives, and I proposed he should take the women at Raffia work, \& so he did' (Clark, 2014: 38).

On 16 October 1908, the Healesville and Yarra Glen Guardian reported on the progress of Fysh's business:

\begin{abstract}
Mr Ernest Fysh, who a little over six months ago established himself here as a photographer, has, we are pleased to learn, been making good progress. Since January last Mr Fysh has taken 400 photos and has printed and sold 3,000 post card views of the district, the distribution of which must be of incalculable benefit to Healesville. Mr Fysh's work is first-class, and he deserves all the support that the local public can give him.
\end{abstract}

On 8 September 1909, Fysh visited Coranderrk Station and took photographs of the Aboriginal residents. Natalie Robarts wrote in her diary: 'We had quite a little pleasant disturbance, Mr. Fish the photographer came to take several photos of the natives, and I proposed he should take the women at Raffia work, \& so he did' (Robarts Diary 8/9/1909 in Clark 2014b: 38).

The success of Fysh's business and his entrepreneurship is demonstrated in the news that he had had to expand his studio and by the fact that in a little over 20 months he had increased his output from 3,000 postcards to over 20,000 cards.

\begin{abstract}
Mr E. Fysh, Healesville's photographic artist, in order to cope with his increasing, business and give greater satisfaction (if that is possible) to his numerous customers, has had built a large and up-to-date studio at his residence, Fernshaw-road, where intending patrons can have their photos taken in the latest style. Mr Fysh's reputation as a photographer is so well and favorably known, that those who wish to have their photos taken, whether on post card, cabinet or enlargement size, cannot do better than pay him a visit. In the short time he has been here he has taken and prepared over 20,000 post-cards, besides picnic parties, family and wedding groups, and an inspection of his work will convince one that Fysh's is the best place to go for photos. [...] photography is a speciality, and his charges are very reasonable. Visitors and others, don't forget to pay Mr. Fysh a visit (Healesville and Yarra Glen Guardian 24/6/1910).
\end{abstract}

Weddings were one of Fysh's specialities, and although Lydon (2005) believes that it is possible that the Coranderrk community commissioned him to take their wedding photographs, I suspect it is more likely that the entrepreneur in him realised the potential market for postcards of Aboriginal weddings at Coranderrk - the sending of cards by local white families to their non-resident kinfolk for example demonstrates the demand. It is possible that some of the images were commissioned by the Aboriginal residents though in the absence of any evidence of this it must remain 


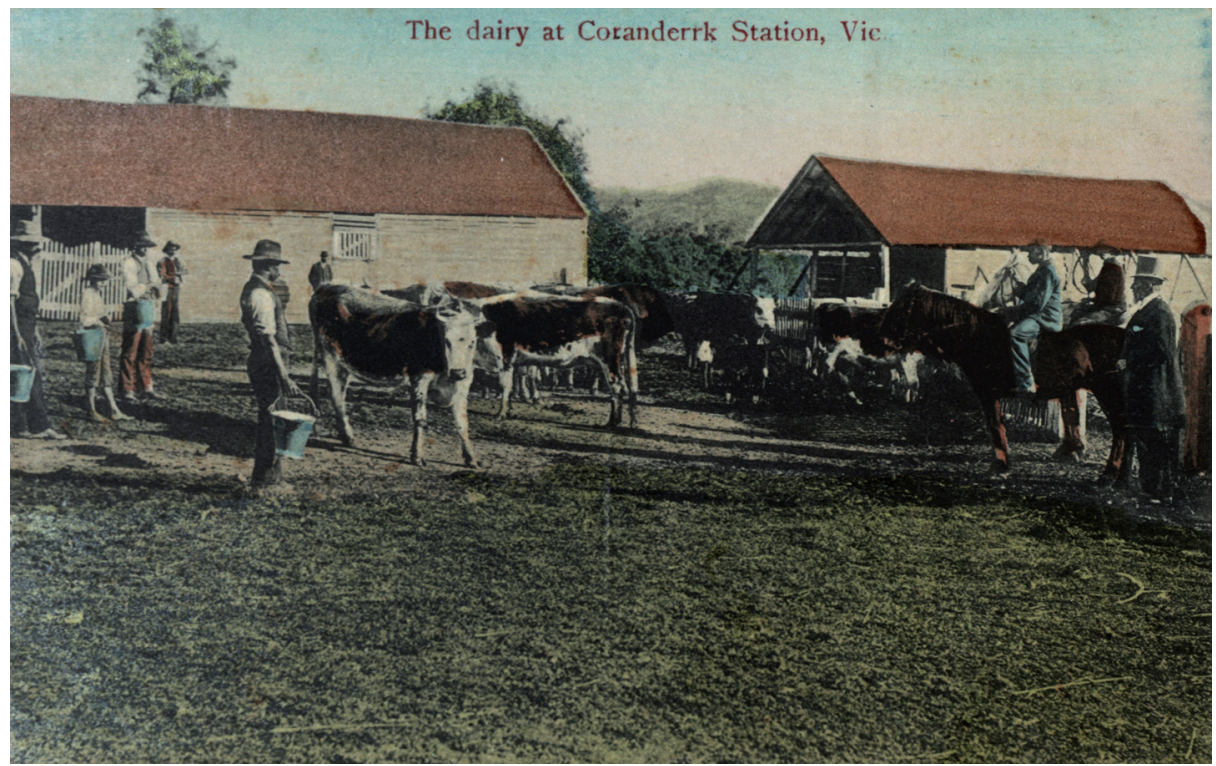

Figure 7.13: The dairy at Coranderrk Station, N.J. Caire photograph. Vic. V.S.M. Series. Printed in Germany. (Author's picture collection)

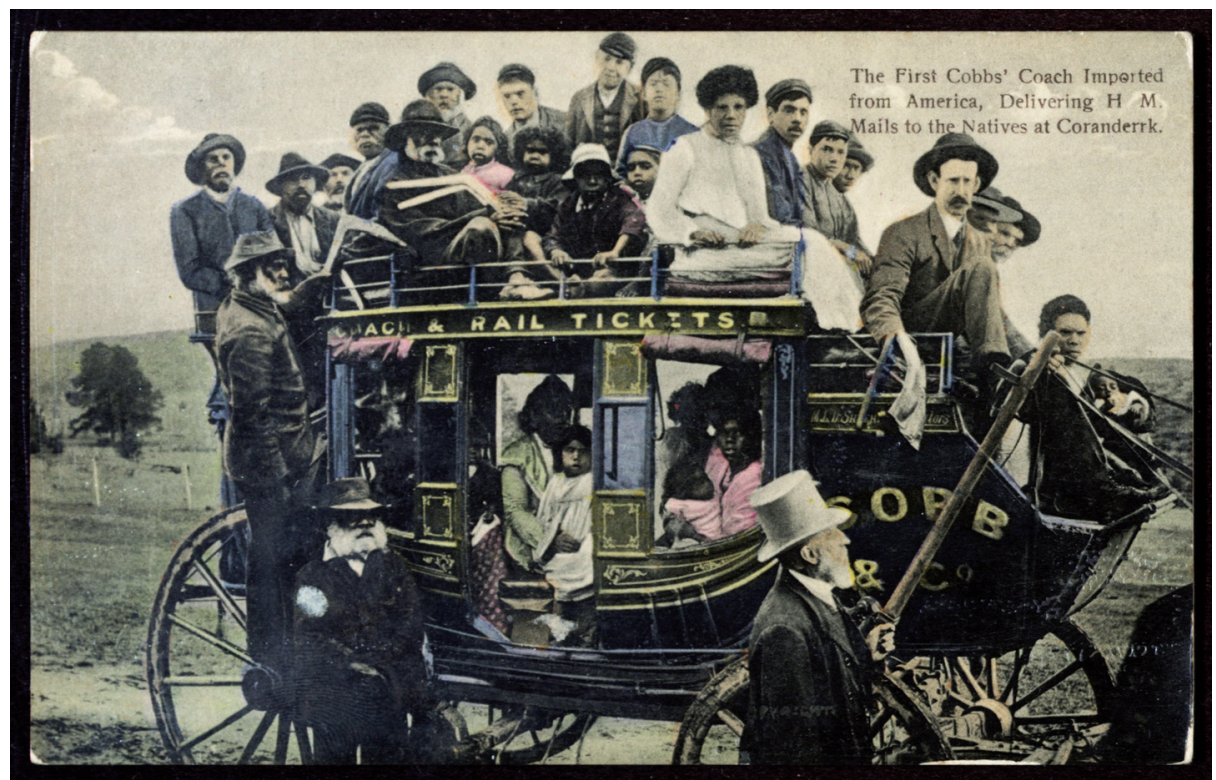

Figure 7.14: The First Cobbs' Coach Imported from America, Delivering H.M. Mails to the Natives at Coranderrk. N.J. Caire photograph. Printed in Germany. (Author's picture collection) 
speculation. The transmission of Coranderrk wedding cards by non-residents would suggest that the images were not taken exclusively for the bride and bridegroom. Of course it is possible that the quid pro quo for the couple in giving their consent to be photographed and granting Fysh reproductive rights was a waiver of the sitting fee and complimentary copies.

Fysh used the pages of the Healesville and Yarra Glen Guardian (25/11/1910) to correct errors in the Healesville Tourist and Progress Association's new penny guide book Tourist's Guide to Picturesque Healesville and District. ${ }^{136}$ He noted that on 'p. 59 Sundays are wrongly excepted from the visiting days at Coranderrk, as by a special edict from the Board, Sunday visiting is expressly allowed'.

People were also motivated by an interest in Aboriginal people regarded as both a 'dying race' and a 'fossil race'. Indeed, in the early 1900s tourist guides often promoted a visit to Aboriginal stations and the purchase of postcards of the stations and their residents as important souvenirs of a soon-to-be extinct race of people (Lydon 2005: 189).

\title{
7.4 Weddings at Coranderrk
}

Ethel Shaw has discussed the importance of events such as weddings in the life of the Coranderrk station:

\begin{abstract}
A wedding on the station caused a happy stir among the people. Like one big family, all were interested in the young, and sometimes old, couple. ... When the wedding day arrived, the church was decorated with flowers and filled with smiling people, all the residents, of course, being guests, and sometimes a few white folk anxious to see an Aboriginal wedding. The ceremony was followed by the wedding feast. This had been much anticipated by the guests, and was thoroughly enjoyed by all. Everyone received a piece of the wedding cake. After a happy speech from the clergyman and a shy response from the bridegroom, the happy couple went to their home, well showered with rice. Often a little dancing and singing followed in the evening (Shaw 1949: 22).
\end{abstract}

Reflecting on weddings at Coranderrk during his parents' tenure as manager and matron of Coranderrk, Oswald Robarts recalled the wedding in 1909 of Eliza and Ted in a piece entitled 'Dusky Beau Brummels and Picturesque Weddings':

Weddings were generally occasions for a lavish display of finery. The preparations of those to whom marriage was no new experience, however, were not so elaborate. In the summer of 1909 love again stole into the heart of Eliza, a widow. Her heart was won by Ted, an unassuming middle-aged widower. The wedding was celebrated in the following year. Whether the strain of the ceremony or a sense of impending doom wrought up her nerves will never be known, but

136 A second edition of the guide was published in 1914. 


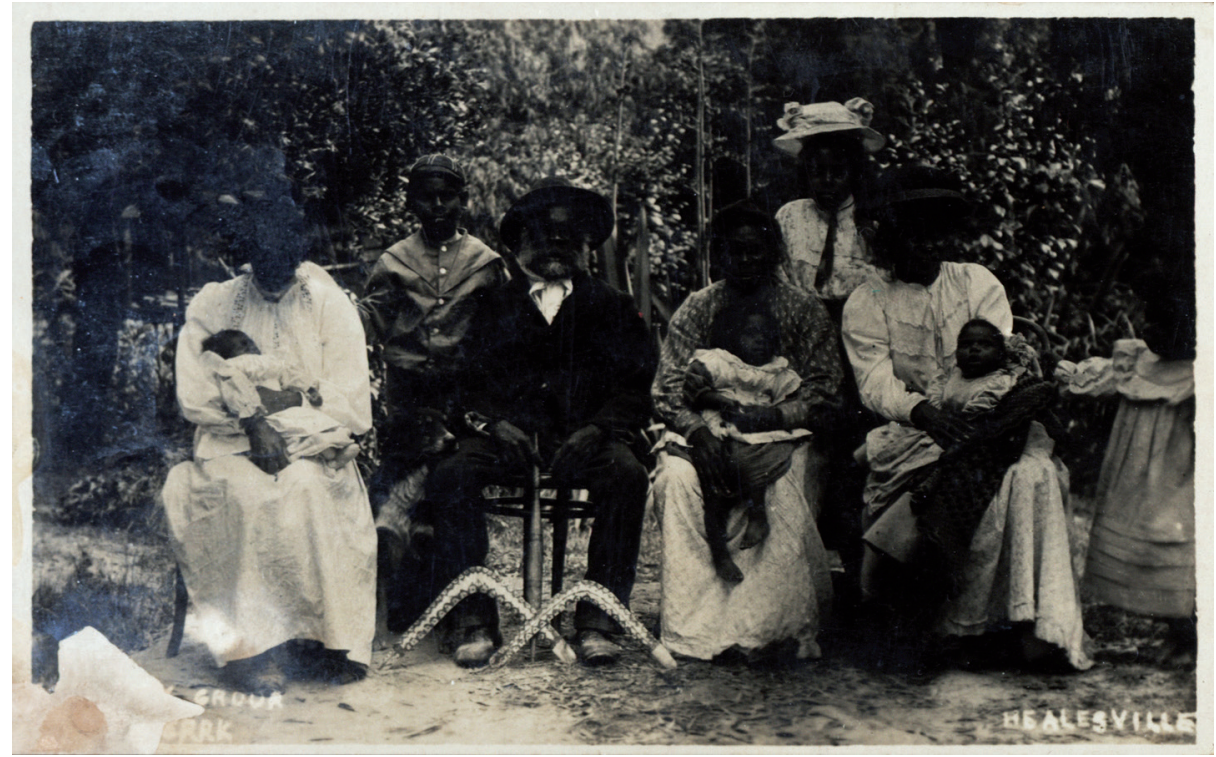

Figure 7.15: Family Group, Coranderrk. Healesville. J. Kercheval, Healesville, Victoria, Australia. (Author's picture collection).

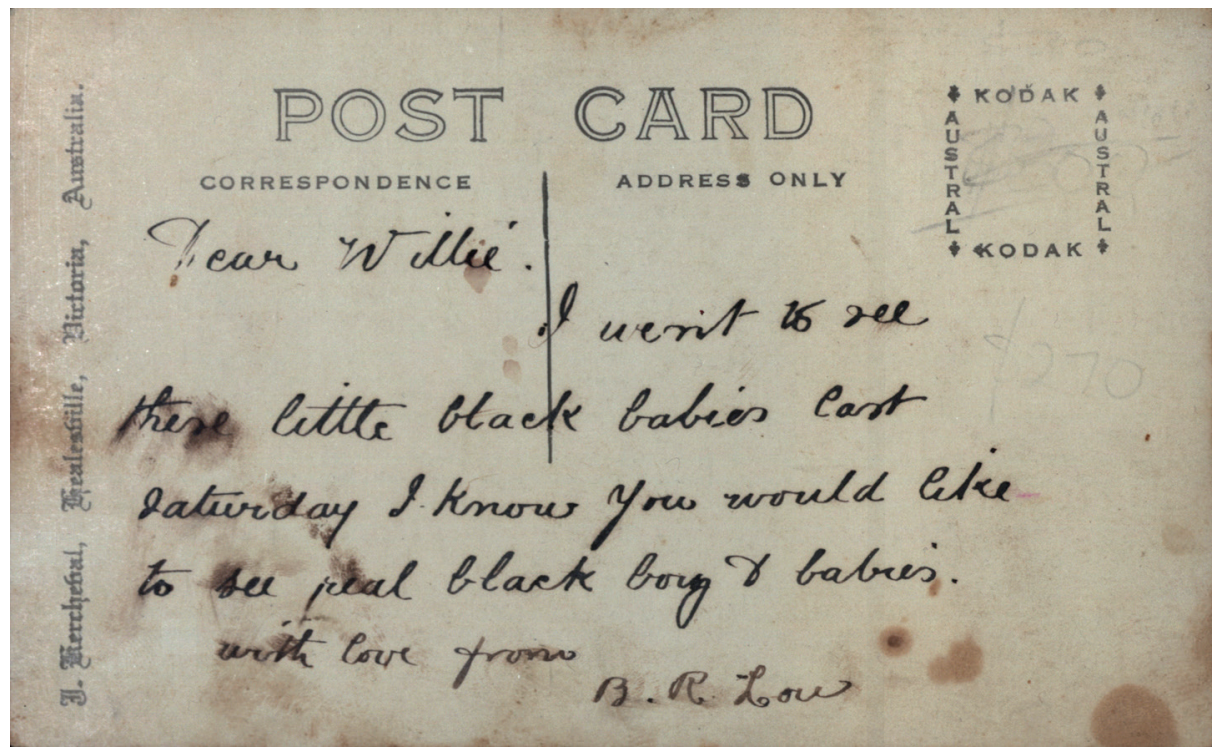

'I went to see these little black babies last Saturday. I know you would like to see real black boys \& babies'. 
after the service, the bride was led weeping from the altar supported on the arm of her husband. She could not be persuaded to face the camera. A few months later, following a distressing "scene" with her husband, she proclaimed her intention of committing suicide. She was seen making off in the direction, of the Yarra, but she returned to the settlement at nightfall. Drenched, but chastened, she complained that the water had been too cold. Domestic differences in the life of the community not infrequently demanded considerable tact in the restoration of peace. For, that reason it was customary during church services for men to occupy one side of the building and women the other. Few women were free from the corroding suspicion that other women had designs upon the affections of their husbands across the aisle, and alleged battings of eyelids were frequently sources of grievances which were fiercely ventilated (The Argus 6 June 1931; Healesville and Yarra Glen Guardian 27 June 1931).

Lydon's (2005: 209) analysis of some of the Coranderrk wedding postcards is that they show events that were in material terms, strikingly elaborate, carefully conforming to European ritual, including formal clothes and shoes, wedding cake, floral bouquets, and bridal parties. According to Lydon, Aboriginal weddings provided station managers and others evidence of the success of their management regime, that 'white weddings' show a triumph of colonization and white progress - yet, she has ignored Oswald Robarts's comment (see above) that the traditional practise of separating men and women from one another in official ceremonies was strictly adhered to in wedding ceremonies at Coranderrk in the early $20^{\text {th }}$ century - colonization had not erased every traditional convention.

John Green reported to the Central Board (see Victoria, 1866: 4), that very early in his time as superintendent at Coranderrk, insisted on the "proper performance of the marriage ceremony, and it is believed that the effect on the minds of the blacks is highly beneficial. They are made to understand that they are no longer mere savages, and that they are entitled to take part in those ceremonials which the blacks in other parts of the colony believe are reserved only for the whites'.

\subsubsection{Five Weddings at Coranderrk in the Same Ceremony, April 1868}

The first wedding at Coranderrk that gained considerable attention was a large service that saw five couples married in the same ceremony. Three ministers were involved in the proceedings (see Figure 7.16).

\section{WEDDING CEREMONY AT THE ABORIGINAL STATION, CORANDERRK}

A correspondent, writing from the Black Station, Coranderrk, Upper Yarra, furnishes an interesting account of a native wedding which took place there last week:-- "The officiating clergymen on the occasion were the Rev. Robert Hamilton, Napier-street church, Fitzroy; Rev. A.M. Ramsay, St. Enoch's, Collins-street; and the Rev. S.L. Chase, of St. Paul's. On arriving on the 3rd - inst. we found everything in course of preparation for the ceremony. The camp seemed quite in a fluster, the young men standing about in groups, laughing and joking, and the girls, looking perfectly clean and neat, were ogling and glancing about most mysteriously. The marriage took place at about two o'clock, in the large room of the station, used for various 


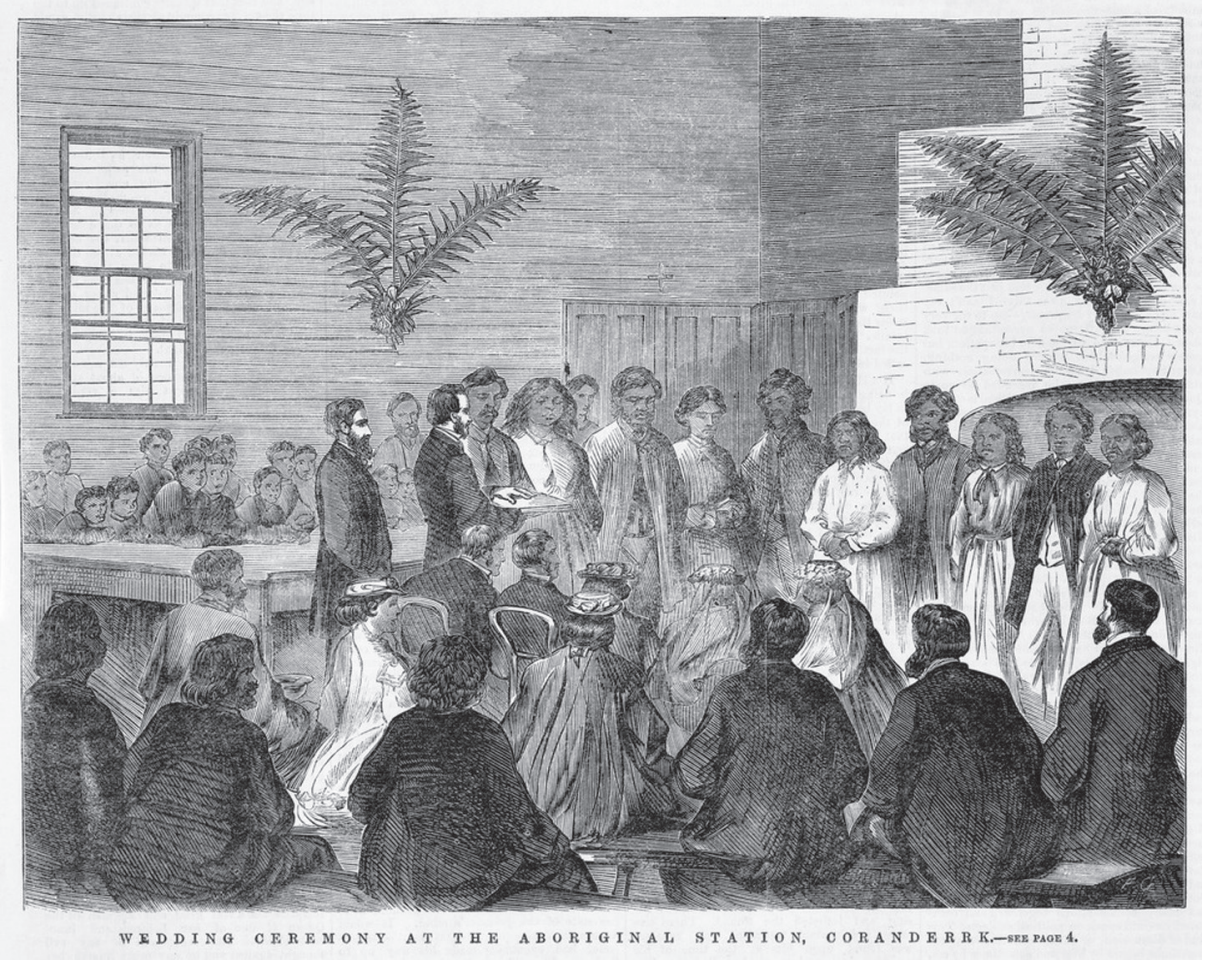

Figure: 7.16: Wedding Ceremony at the Aboriginal Station, Coranderrk. Illustrated Australian News 25/4/1868; State Library of Victoria Pictures Collection IAN25/04/68/8

purposes, as a school, a dining-place, and a church. This chamber, thirty by twenty-four feet, was quite full, partly with blacks and partly with visitors from neighboring homesteads. The brides and bridegrooms stood side by side at one end, while chairs and forms accommodated the visitors at the other. The Rev. Mr Hamilton performed the ceremony, assisted by the Rev. Mr Ramsay. Everything proceeded in the most quiet and orderly manner. In truth, I never saw amongst white people more attention and more anxiety to have the marriage performed in decency and good order. After the ceremony, the children sang several hymns and songs, concluding with the 'National Anthem,' and I assure you that not in any school did I hear the music better rendered. The room was then cleared, and the tables laid with abundance of bride cake, tea and other pleasant things, of which all partook heartily. It appears that this is the fourth time that the ceremony of marriage has been performed at Coranderrk. The first and second times, one couple only were married; the third time, two couples; and this last and fourth time, five couples, evidently showing that a desire for proper matrimonial relations is growing among the blacks. It appears that there is among them a singular superstition which prevents the mother of the girl who is about to be married from coming within sight of the father of the young man, and the mother of the young man from seeing the father of the girl; they believe that their hair would necessarily turn grey. Living, however, as they do at Coranderrk, the parents were unable to avoid meeting each other; and at first it appears that considerable surprise was felt that no evil consequences ensued. This, of course, led to the abandonment of the 


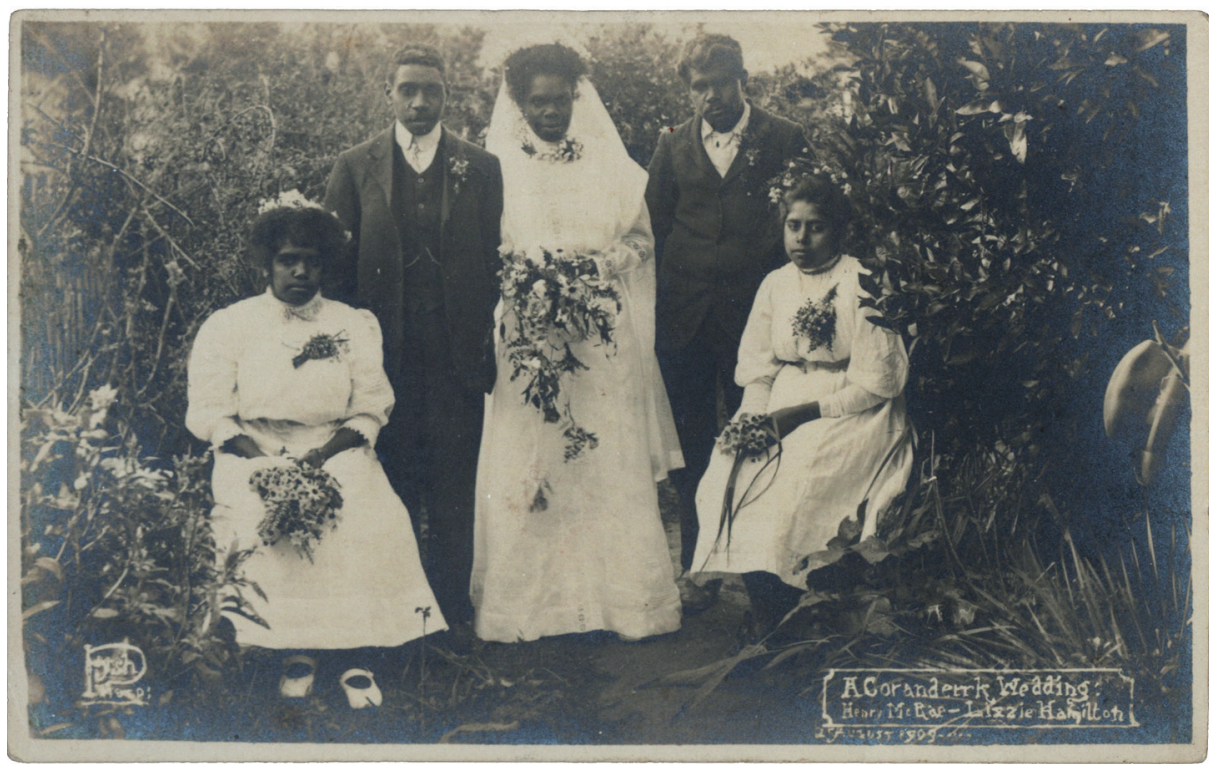

Figure 7.17: A Coranderrk Wedding: Henry McRae - Lizzie Hamilton 2 August 1909. Ernest s. Fysh, photographer. (Author's picture collection)

superstition, which now, I am told, those at the station laugh at. ... After the marriage, in the evening, some speeches were made by the blacks, and several native songs were sung. Simon, the chief of the Yarra tribe, spoke impressively in the native tongue, and as no translation was attempted, it is probable that some reference was made to those who had deserted them, and who were still absent. Another spoke in English, and in short emphatic sentences told how much he was pleased with what had taken place, and how much he regretted that those who had been married before in the same place had gone away. The evening was spent pleasantly and harmoniously with other speeches and songs, and concluded as usual with prayer and a hymn, all the blacks shaking hands with all the whites present. .. (Illustrated Australian News for Home Readers, 25/4/1868).

\subsubsection{Hugh McRae and Lizzie Hamilton Wedding, 2 August 1909}

Massola (1975: 42) has noted that 'Weddings always created much excitement on the station. The first that took place after Mr Robarts became manager was that of Henry McRae and Lizzie Hamilton. He is described by Mrs Robarts as being a nice young lad, and Lizzie is pronounced to be a nice and well-behaved young girl. Lizzie's father, Frank Blair, bought her a wedding dress' (see Figure 7.17).

Natalie Robarts continued her diary entry about Frank Blair: 'He went to town to buy it, and as he had no money to take him down some of the people good naturedly subscribed about 10/- so what with $€ 1$ sent by an uncle of Lizzie she is particularly 
well off ... everyone on the Station has a good word for Lizzie' (Robarts Diary 11/8/1909 in Clark 2014b: 37).

Lizzie's wedding day, and such a beautiful day, full of sunshine ...The church was a picture, the women decorated it with wattle blossom \& white Cherry plum - it is the prettiest church decorations I have seen, these people seem to have a natural gift, it was artistic and graceful. The school room also looked nice. I have put pictures on the walls \& it brightens the scene. All our people are very happy today. Lizzie looked very nice in her white muslin dress \& veil \& wreath which consisted of Cherry Plum blossoms ... But there was one disappointment. The new furniture for their cottage, though ordered ten days in advance, had not arrived! However the wedding breakfast was delightful. Miss Shaw made an elaborate wedding cake, I also gave Lizzie a fancy cake. Mrs Wandin (what should we do without her!) made all the sandwiches \& six large cakes, the people also contributed £1.0.0 towards the supper ... (Robarts Diary 25/8/1909 in Clark, 2014b: 37f).

\subsubsection{Willie Russell and Julia Sherwin, March 1910}

Figures 7.18-7.19 are two different postcards from the wedding of Willie Russell and Julia Sherwin, in March 1910. The author has a personal copy of Figure 7.18. On the reverse the sender has written:

This is a photograph of Mr \& Mrs Russell \& 2 more that were married recently (Woodford \& I don’t know the girls name) see how he is blushing.

Peterson's (2005: 19) observation of Figure 7.19 is that the woman, Julia Sherwin, is being married in conventional European bridal gowns and the men are in suits. He considers this photograph is typical of the wedding photographs that were taken at Coranderrk. With the couple are three attendants: a bridesmaid (seated) and two groomsmen - one sitting, the other standing.

\subsubsection{John Terrick - Ellen Darby Wedding, 7 July 1910}

Natalie Robarts mentioned the wedding of John Terrick and Ellen Darby in passing: 'John Terrick's wedding is over [he married Ellen Darby] it all passed off well, Baroness de Pury, her two sons \& two nieces came to see the wedding (Robarts Diary 7/7/1910 in Clark, 2014b: 49) (see Figure 7.20). The wedding made the newspapers:

VICTORIA. MELBOURNE. July 10.

An aboriginal wedding took place at Coranderrk on Thursday between "Johnny" "Terrick", a widower, nearly 70 years of age, one of the few remaining blacks of the Yarra tribe, and Ellen Darby, from Lake Tyers, widow, 35 years of age. Baroness De Pury made the bride a present of a wedding dress for the occasion (The Register, 11/7/1910). 


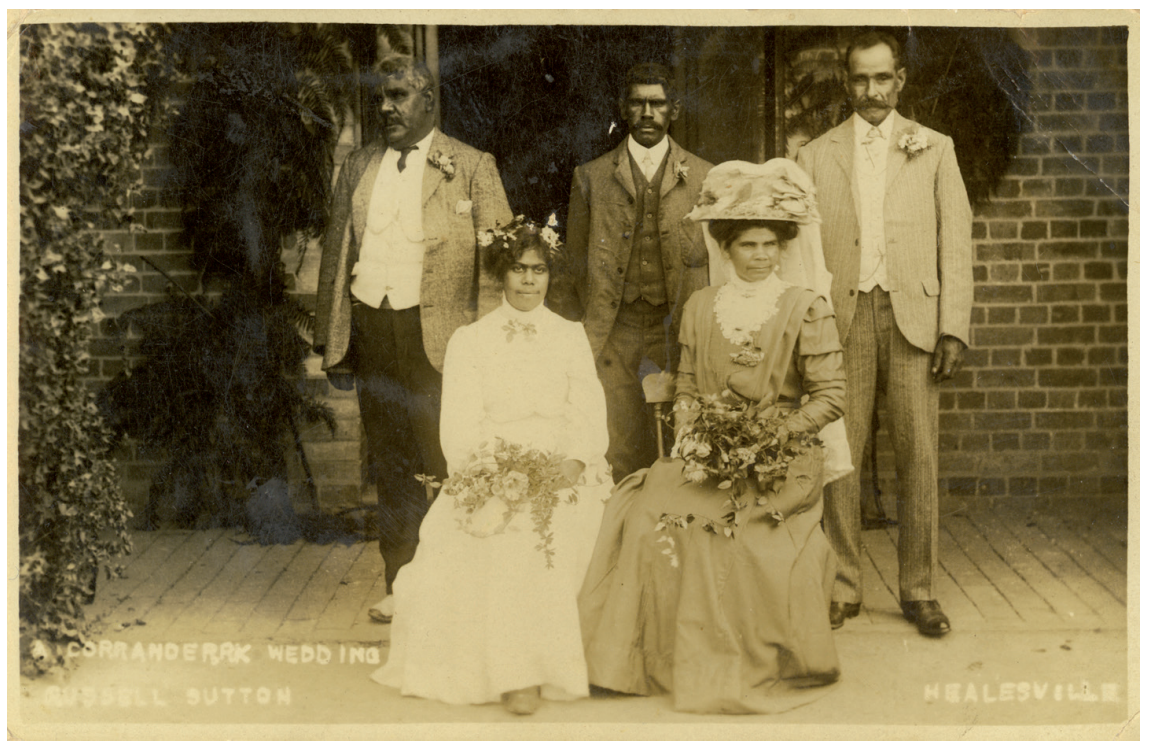

Figure 7.18: A Coranderrk Wedding Russell Sutton Healesville, J. Kercheval photographer, March 1910 (Author's picture collection). Note that Woodford Robinson, left hand side, is once again standing in the pose he generally takes when he is being photographed - standing away, averting his gaze from the camera.

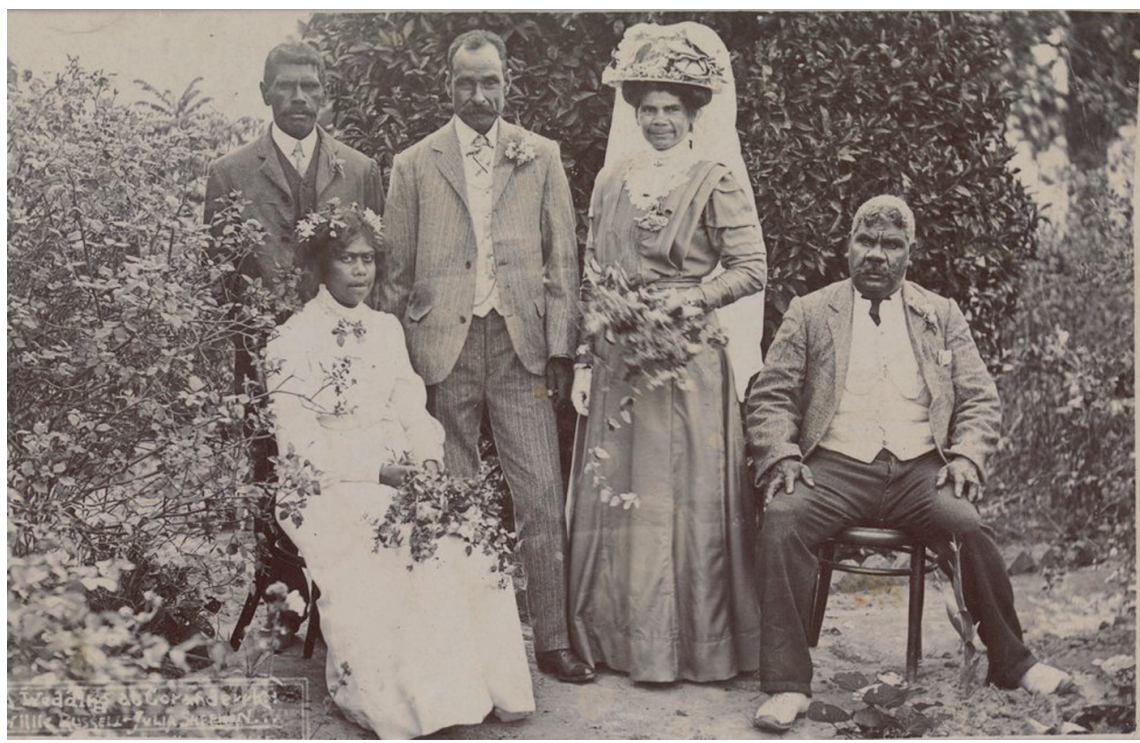

Figure 7.19: A Wedding at Coranderrk: Willie Russell - Julia Sherwin Postcard March 1910, Ernest G. Fysh, Healesville, Victoria. State Library of Victoria Pictures Collection H42691. 


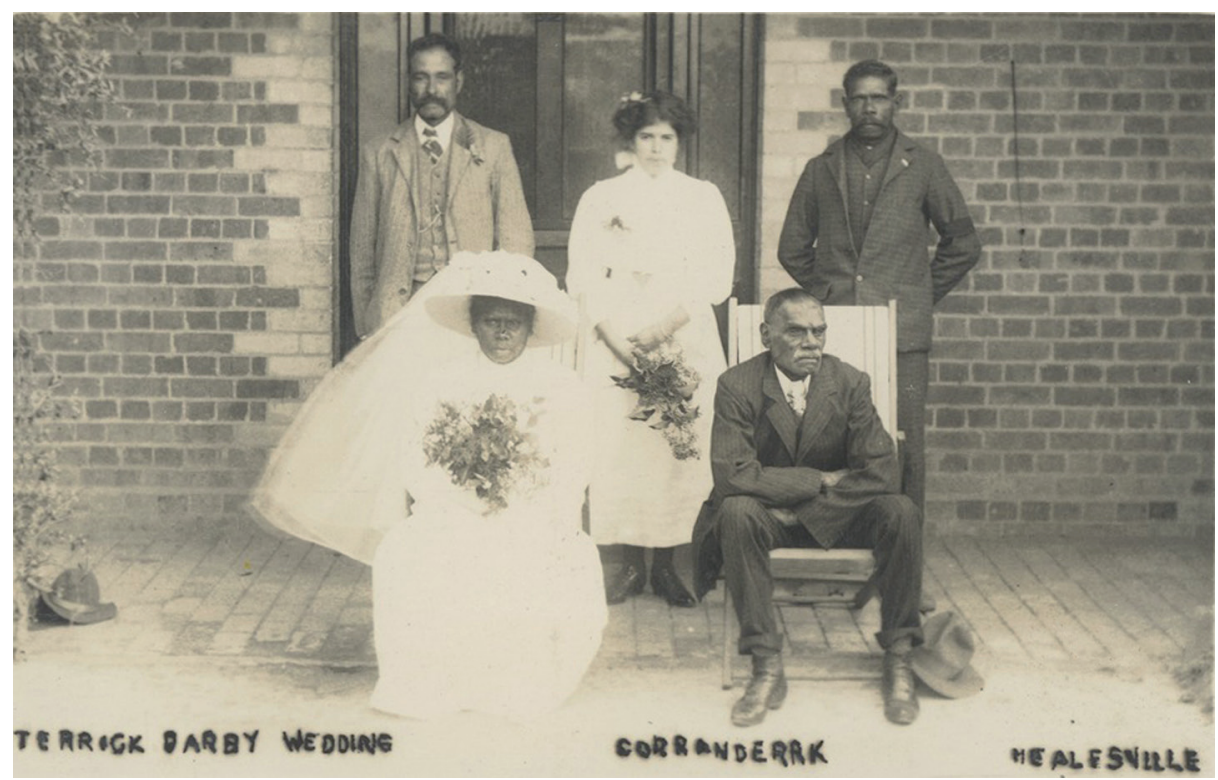

Figure 7.20: Terrick Darby Wedding, Corranderrk, Healesville. [Presumably J. Kercheval, photographer] Postcard, State Library of Victoria Pictures Collection H2012.78/4

An aboriginal wedding took place at Coranderrk on Thursday between "Johnny", Terrick." a widower, nearly 70 years of age, and one of the few remaining blacks of the Yarra tribe, and Ellen Darby, from Lake Tyers, a widow, of 35 years of age. Mr. C.A. Roberts, superintendent performed the ceremony. Baroness de Pury made the bride a present of the wedding dress for the occasion (The Argus, 11/7/1910; Bairnsdale Advertiser and Tambo and Omeo Chronicle, 12/7/1910).

A NOVEL WEDDING. TWO ELDERLY ABORIGINALS MARRIED.

Melbourne, Monday.

A novel wedding was celebrated at the Coranderrk aboriginal station on Saturday by the manager. The contracting parties were two full-blooded blacks, John Terrick and Ellen Darby, a widower and a widow, grandfather and grandmother respectively. The bridegroom is 75 years of age. The church was crowded. The bride, who was supported by a dusky bridesmaid, wore a cream Sicilian gown and a gossamer veil (Barrier Miner, 11/7/1910).

\subsubsection{Alick Mullett and Violet Manton Wedding, October 1910}

In October 1910 Alick Mullett married Violet Manton (see Figure 7.21). The local paper ran the following story on the wedding: 


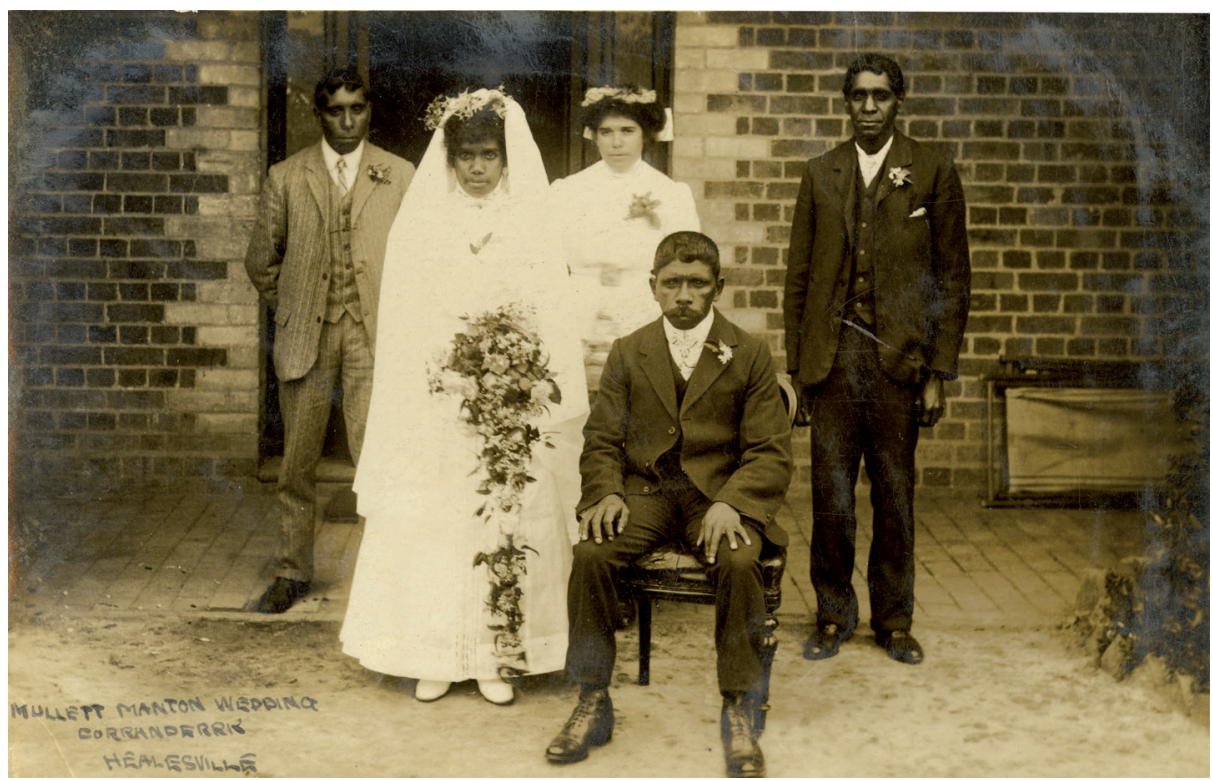

Figure 7.21: Mullett Manton Wedding Corranderrk Healesville. J. \& O.H. Kercheval Photographer, Healesville. (Author's picture collection)

'We seen this bride \& didnt she look fine in all her array \& just as proud as any white bride would be, they dearly love white clothes their everyday clothes are gray in color, but they think if they get married in white they are as good as we are \& poor devils nobel they are to, I often pity the blacks ours are a peaceful lot, I cant understand the treatment they get'.

ORANGE BLOSSOMS, MULLETT-MANTON.

A very pretty and popular wedding took place at Coranderrk last Thursday afternoon, when Miss Violet Manton was united to Mr Alick Mullett by the manager, Mr C. Roberts. The weather was remarkably fine, the bride was comely, and the bridegroom as happy a man as you might meet in a day's march. There was a great gathering of guests and visitors. The little church, gaily decorated with ferns, dogwood, blossom, and trails of clematis, was thronged, and the singing during the service most enjoyable. The bride wore white muslin, trimmed with embroidery, a pair of neat white shoes, and a net veil, and carried a shower bouquet of roses from the 'manager's garden. But the loveliest feature in her costume was the use made of the native clematis, now in full bloom beside the Coranderrk River, the white, starry clusters on their slender green trails being twisted into a wreath for her dark hair, and trailing in a shower from the roses and maidenhair of her bouquet. She was attended by two pretty, bridesmaids, the Misses Maggie Wandin and Emma Patterson, also dressed in white, with wreaths and bouquets of roses and maidenhair. Mr Alick M'Crae and a cousin of the bride acted as groomsmen. Mr. and Mrs Mullett afterwards held a reception at the house of the bride's mother, where the many pretty and useful presents were displayed. No fewer than five wedding cakes furnished forth the subsequent banquet and dance held at night in Coranderrk Hall. The wedding party was much photographed by both local photographers; and already there are many inquiries for mementoes of the happy occasion (Healesville and Yarra Glen Guardian, 28/10/1910). 


\subsubsection{William Logan and Priscilla Johnson Wedding, 18 July 1917}

Natalie Robarts wrote a long entry in her diary about the wedding of William Logan and Priscilla Johnson.

We had a wedding yesterday. William Logan who has returned from Bunyap ${ }^{137}$ [sic] chose Priscilla Johnson for his wife. Willie is such a nice lad that I only hope Priscilla will prove to be the right woman - unfortunately she is enceinte. Time will tell whether the child is one soldier boy, or purely a little Aborigine! Since Priscilla was sent to the station, being rescued from the soldier's camps she has behaved very well \& has given no trouble. The wedding was a nice one in every aspect. The bride was dressed in white silk, with a veil \& a little wreath made from white heath \& tiny pink roses, carrying a bouquet of sweet smelling violets as also did the bridegroom, best man, \& brides maids. The church was very nicely decorated. The school room was also decorated with wattle blossom \& gum leaves where the 'wedding feast' took place. A large table was erected. Strips of calico provided by me \& another (under clothing material which had been given out weeks ago \& not yet in the making) took the place of table cloths, baking powder tins wrapped around with paper \& filled with wattle blossom decorated the wedding table. All the station was present, each family contributing something towards the feast \& also bringing their own cups \& plates \&c \&c. 'Café au lait' was made also tea. When all were present Grace was sung standing, \& all had a good "tuck in". Annie Manton was telling me today that she made two 'puddins' big ones too, \& they liked them so much that they wanted two helpins! There was, I believe, a speech made, then the two Alices had a real good time by preaching away to willing ears, \& they left about nine o'clock very quietly \& almost solemnly. I gave the bride a flower vase \& a table cover which Natalie took a pleasure in running up. Willie received a silk tie \& Louie who works in the house just now was allowed to make a box full of biscuits (Robarts diary 19/7/1917 in Clark, 2014b: 64f).

\subsection{A Congregational Minister Visits Coranderrk, September 1917}

In September 1917 an English Congregational minister visited Coranderrk whilst he was attending a convention in Healesville. He took numerous photographs of his visit (see Figures 7.22-25). These are private photographs of Coranderrk, so they have never been published. Presumably there exist many other similar photographs taken by the many tourists who visited Coranderrk. These non-commercial images are a unique archive and we are fortunate that they have survived and are available as a resource to this study. ${ }^{138}$ Figure 7.23 shows a man, I believe to be Lanky Manton, making a fire with a firestick being watched by two young girls, one of whom has her own little grass basket. Lanky Manton (partially obscured) and the same two girls are found in Figure 7.24 which includes a much larger family group.

137 Bunyip township, 77km east of Melbourne.

138 The author purchased these photographs through an auction on Ebay. 


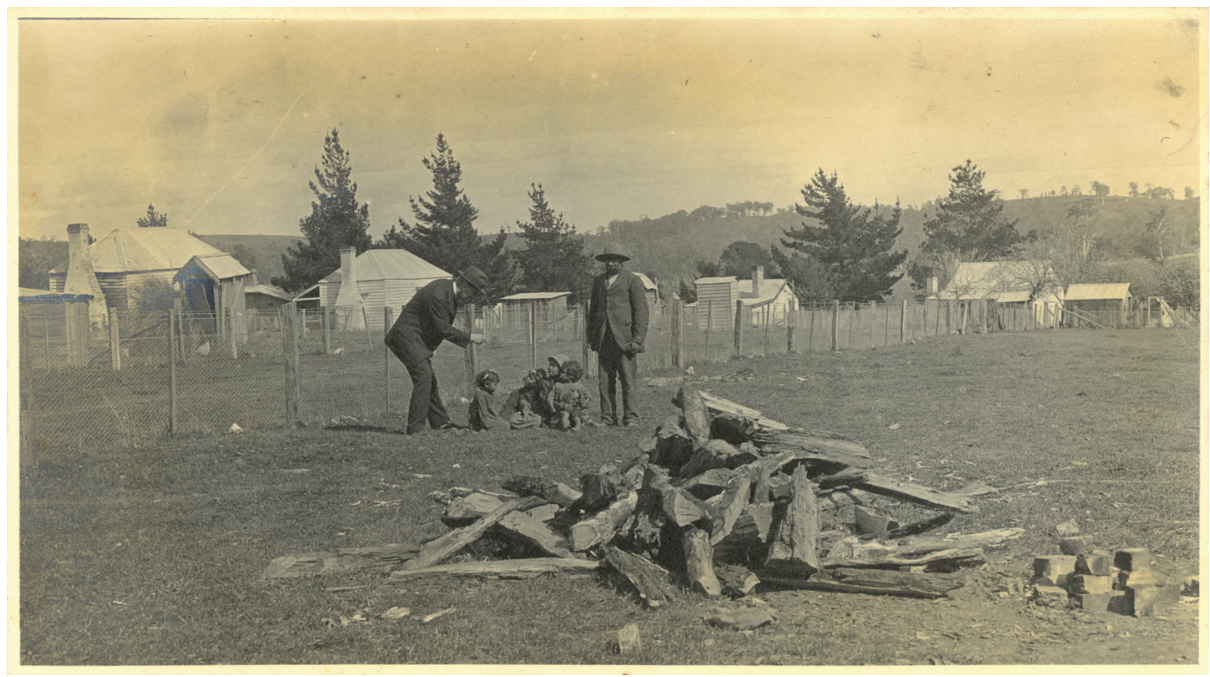

Figure 7.22: Coranderrk Aboriginal Settlement, Vic. Sept. 1917. (Author’s picture collection)

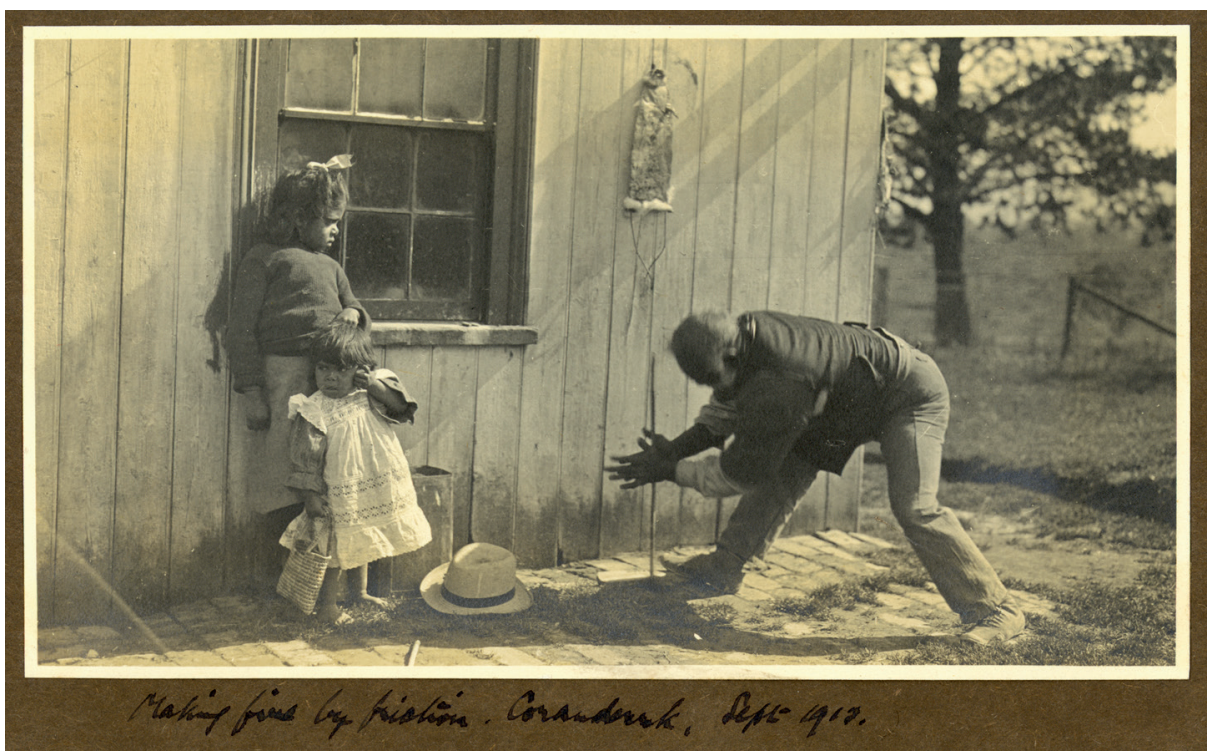

Figure 7.23: Making fire by friction, Coranderrk. Sept. 1917. (Author’s picture collection) 


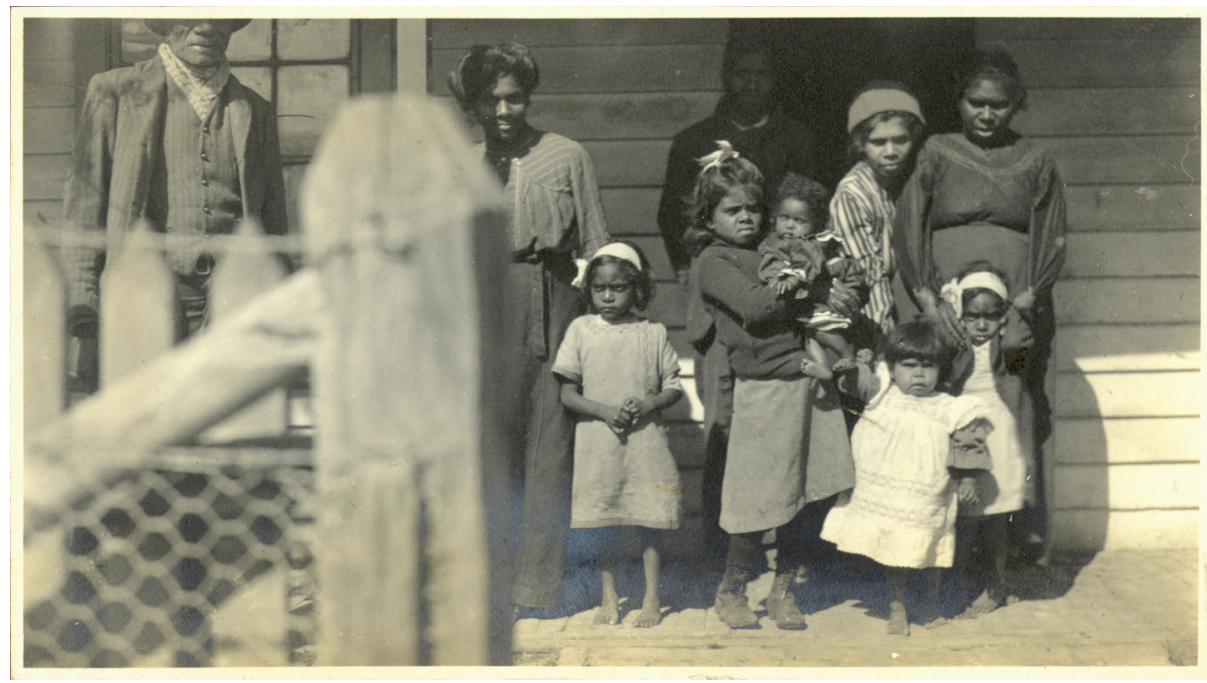

Figure 7.24: Another family, as above. (Author's picture collection) Man on left hand side (partially obscured) is Lanky Manton.

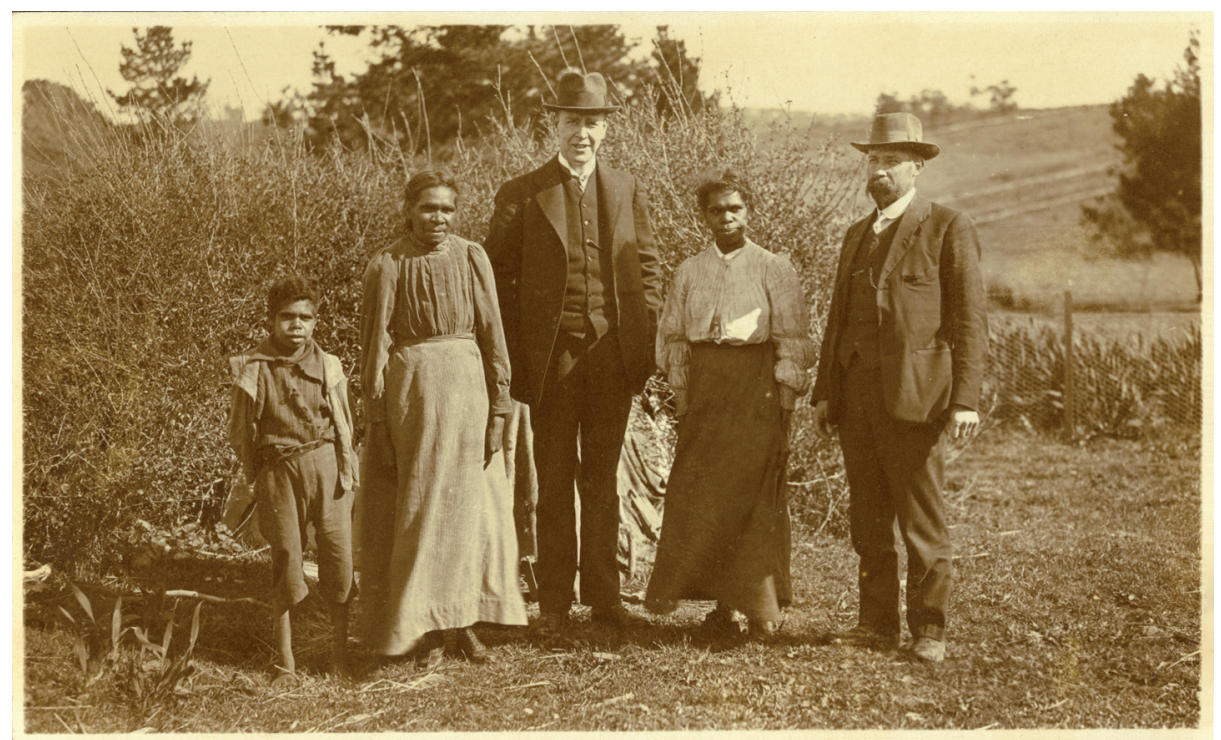

Figure 7.25: Coranderrk Aboriginal Reservation, Vic. Sept. 1917. (Author’s picture collection). 


\section{Select References}

Cato, J. (1955). The Story of The Camera in Australia. Melbourne: Georgian House.

Clark, I.D. (2014). The Last Matron of Coranderrk: Natalie Robarts's Diary of the Final Years of Coranderrk Aboriginal Station, 1909-1924. Charleston: Createspace Independent Publishing.

Conor, L. (2006). 'This striking ornament of nature: the 'native belle' in the Australian colonial scene. Feminist Theory. 7: 197-218.

Haebich, A. (2009). Unpacking Stories from the New Norcia Photographic Collection. New Norcia Studies. 55-62.

Kleinert, S. (2006). Aboriginality in the city: re-reading Koorie photographs. Aboriginal History. 30: 69-94.

Kovacic, L. (2006). What Photographers Saw: Aboriginal People and Australian Colonial Experience. In P. Edmonds \& S. Furphy (Eds.). Rethinking colonial histories: new and alternative approaches (89-104). Melbourne: Department of History, University of Melbourne.

Lydon, J. (2005). Eye Contact Photographing Indigenous Australians. Durham: Duke University Press. MacKenzie, J.M. (1985). Propaganda and Empire: the Manipulation of British Public Opinion, 1880-1960. Manchester University Press, Manchester.

McMurray, F.M. (Ed.) (1915). The Word Visualized for the Class Room 1000 travel studies through the stereoscope and in lantern slides, classified and cross referenced for 25 different school subjects: Teachers' Manual. New York: Underwood \& Underwood.

Malin, B.J. (2007). Looking White and Middle-Class: Stereoscopic Imagery and Technology in the Early Twentieth-Century United States. Quarterly Journal of Speech. 93(4): 403-424.

Massola, A. (1975). Coranderrk A History of the Aboriginal Station. Kilmore: Lowden Publishing. Morton, J. (2006). Seeing Eye to Eye: Photography and the Return of the Native in Aboriginal Australia. Arena Journal. 27: 47-59.

Peterson, N. (2006). Early $20^{\text {th }}$ Century Photography of Australian Aboriginal Families Illustration or Evidence? Visual Anthropology Review. 21 (1-2): 11-26.

Pitkethly, A. \& Pitkethly, D. (1988). N.J. Caire Landscape Photographer. Rosanna: The Authors. Victoria. (1866). Fifth Report of the Central Board Appointed to Watch over the Interests of the Aborigines of the Colony of Victoria. Melbourne: John Ferres, Government Printer. 